Article

\title{
Boosting Customer E-Loyalty: An Extended Scale of Online Service Quality
}

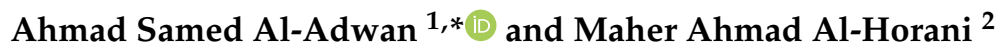 \\ 1 Electronic Business \& Commerce Department, Business School, Al Ahliyya Amman University, \\ Amman 19328, Jordan \\ 2 Business Adminstration, Business School, Al Ahliyya Amman University, Amman 19328, Jordan; \\ maher@ammanu.edu.jo \\ * Correspondence: a.adwan@ammanu.edu.jo
}

Received: 12 November 2019; Accepted: 29 November 2019; Published: 3 December 2019

\begin{abstract}
The Customer trust, satisfaction and loyalty with regard to the provision of e-commerce services is expected to be critical factors for the assessment of the success of online businesses. Service quality and high-quality product settings are closely linked to these factors. However, despite the rapid advancement of e-commerce applications, especially in the context of business to consumer (B2C), prior research has confirmed that e-retailers face difficulties when it comes to maintaining customer loyalty. Several e-service quality frameworks have been employed to boost service quality by targeting customer loyalty. Among these prominent frameworks is the scale of online etail quality (eTailQ). This scale has been under criticism as it was developed before the emergence of Web 2.0 technologies. Consequently, this paper aims to fill this gap by offering empirically-tested and conceptually-derived measurement model specifications for an extended eTailQ scale. In addition, it investigates the potential effects of the extended scale on e-trust and e-satisfaction, and subsequently e-loyalty. The practical and theoretical implications are highlighted to help businesses to design effective business strategies based on quality in order to achieve enhanced customer loyalty, and to direct future research in the field of e-commerce.
\end{abstract}

Keywords: e-trust; reputation; e-service quality; e-loyalty; e-satisfaction; etailq; e-satisfaction; website design

\section{Introduction}

Online businesses are often challenged when it comes to keeping their existing customers while simultaneously targeting new customers [1]. In the online environment, Anderson and Srinivasan [2] (p. 125) refer to loyalty to as "a customer's favorable attitude towards an electronic business, resulting in repeat purchasing behavior". E-loyalty denotes a consumer's willingness to purchase products/services from a specific website, with the consumer being unlikely to shift to buy from other websites [3]. Online loyalty is related to convenience, price of products/services, privacy, product presentation, quality of customer support and competency in terms of meeting delivery commitments [4]. In both online and offline shopping contexts, customer acquisition is viewed as a high cost process, and customer relationships tend to be unprofitable in the early years [5]. However, in later years, when the outgoing costs associated with serving loyal customers decreases, and the number of their purchases increases, such relationships generate significant returns. This economic pattern of early losses followed by increasing revenues, is essentially amplified in online environments. The costs associated with acquiring customers are often noticeably higher in online than in traditional channels.

Thus, the literature points out that the value of loyalty in online environments is greater than that found in physical/traditional environments [6]. This assumption relates to various economic 
and competitive factors. For example, unlike a traditional environment, the initial cost of acquiring customers through online channels is much higher. Consequently, without customer retention and repeated purchases over time, high levels of financial revenue will remain elusive. Furthermore, since online stores can easily expand their diversity in terms of products/services, loyal customers are inclined to consolidate their buying activities with only one supplier [4]. This means that online stores can sell more and offer a wider range of services/products to their loyal customers. Moreover, another economic benefit can be achieved through referrals from loyal customers. Loyal customers constantly refer new potential customers to stores/suppliers, generating additional generous sources of profit [6]. Since the cost of acquiring these referred customers is so little, the online store commences to generate earnings far earlier in their life cycle [7]. Furthermore, in all industries, companies now devote considerable efforts to harnessing the capabilities of the Web to create unique value for customers [8]. By doing so, these companies are going to achieve much more profitable relationships with customers compared to those rivals which are slow to recognise the potential of the Web for their customers.

According to Srinivasan et al. [9] (p. 41), developing customer e-loyalty is recognized as a huge challenge since "competing businesses in the world of electronic commerce are only a few mouse clicks away", and the customers are able to assess alternative choices with little effort and time. However, in contradiction of the above view that questions the loyalty of online customers, Shankar et al. [10] state that online customers not only buy frequently on websites with which they have developed a decent relationship, but also are inclined to combine their purchases using major online retailers, demonstrating a considerable tendency towards loyalty. E-loyalty brings superior revenue to the online retailer. Specifically, Van-Riel et al. [11] explain that loyal online customers buy and spend more than newly-acquired customers. In addition, they can be served with minimal functional costs. These previous studies indicate that e-loyalty is valuable for e-retailers because it strengthens their survival chances in the strong competition environment encountered on the Internet.

Customer satisfaction is vital for the sustainability of all businesses. E-satisfaction is referred to by Anderson and Srinivasan [2] (p. 125) as "the contentment of the customer with respect to his or her prior purchasing experience with a given electronic commerce firm". Customer satisfaction reflects the extent to which customers' expectations with regard to a product/service are fulfilled, which can act as a demonstration of consistency between the expected and the actual performance with regard to the purchased product/service [5]. In other words, customer satisfaction is considered as the outcome of a comparison between expectations and experience, and satisfaction is attained when the final deliverable(s) meets or even exceeds the customers' expectations. Moriuchi and Takahashi [1] point out that satisfaction evaluates a customer's overall purchasing and consumption experience in terms of a product/service over a period of time. The more the gap between expectations and actual performance is reduced, the greater is the consumer's satisfaction. Alam and Yasin [12] state that when customers are satisfied, and their expectations have been met or exceeded by the service provider, the customer's intention to repurchase is most likely to reinforced. Thus, e-satisfaction is a fundamental factor when it comes to retaining customers, and subsequently this has a direct effect on customer loyalty [13-15].

Trust is an essential component in the process of online shopping decision-making because it is recognized as one of the main critical aspects in terms of developing successful and sustainable relationships with customers [16-18]. Trust represents a set of beliefs that a customer has with respect to some characteristics of a service provider and its future behaviour [19]. Such beliefs relate to the actual delivery of a promised service. Trust existence is fundamental for customers, especially during the first-time exchange with a service provider. However, trust develops as the relationship is developed due to the additional experience that the customer gains. Although the literature highlights several dimensions of trust, the perceptions of benevolence and honesty are the most important ones. Perceived honesty represents the degree to which customers believe that a service provider is sincere, and capable to keeping its promises. On the other hand, benevolence demonstrates the extent to which a customer believes that a service provider will not engage in opportunistic behaviour and is concerned about the customer's welfare, and that its ultimate goal is seeking joint benefits. Similarly, it has 
been assumed that trust is a result of beliefs that contend with competence (the ability of the service provider to accomplish and meet customer's expectations and needs), integrity (the service provider's promise-keeping and honesty), predictability (the consistency of the service provider's behaviours), and benevolence (the service provider's motivation and instances of it acting in the customer's interests) [20]. The above-mentioned dimensions of trust can be applied to all commercial contexts, but trust has a particularly great impact in e-commerce, as it is considered by McKnight and Chervany [21] as "an excursion beyond the unknown into the unknowable". Therefore, Ribbink et al. [22] point out that e-trust is viewed as "the degree of confidence customers have in online exchanges or in the online exchange channel". The establishment of e-trust can significantly reduce risk perceptions related to the use of a service or the performing of an exchange.

\section{Study Significance and Rationale}

E-trust and e-satisfaction have a pivotal role to play in developing e-loyalty. Many scholars have confirmed that e-trust and e-satisfaction impact e-loyalty at an individual level (e.g., [13,23], or in a chronological sequence "e-trust $\rightarrow$ e-satisfaction $\rightarrow$ e-loyalty" (e.g., [5]). However, despite the empirical evidence that endorses the significant influence of e-satisfaction and e-trust on e-loyalty, investigating the determinants of e-satisfaction and e-trust has been narrowly understood in the process of developing e-loyalty. Accordingly, it is important to investigate the role of potential components as critical determinants of e-satisfaction and e-trust in the model of e-loyalty. Thus, the research model employs the eTail quality (eTailQ) scale developed by Wolfinbarger and Gilly [24] which uses e-service quality to predict e-trust, e-satisfaction and e-loyalty. ETailQ in this study is measured "from the beginning to the end of transaction, including information search, website navigation, ordering, interactions, delivery and satisfaction with the ordered product" (p. 183). The concept of eTail quality embraces facets related to online transactions as well as offline fulfillment, which have been scarcely examined in previous research. An online consumer's repurchasing decision is based on complex assessments of the full service offer. The majority of transactions commence online and are completed offline. However, previous empirical studies have overlooked the distinctive complementary roles of offline fulfillment and website performance in investigating the development process of e-loyalty. For instance, previous studies have mainly focused on website quality [25], interactivity with the website [26], service quality [27], website design [28], or website [29]. While these studies offer a framework for evaluating the eTailQ scale, they fail to recognize the fact that eTailQ is not solely about consumer interaction with a website [30].

Consequently, this study conceptualizes eTailQ as a multidimensional scale, examining the distinctive role of each eTailQ dimension on the process of developing e-loyalty. Specifically, the four adopted dimensions of eTailQ are: security/privacy, fulfillment/reliability, customer service and website design. Several studies, such as that of Chang and Wang [31], have offered a comprehensive model and framework to explain the process of developing e-loyalty. The models contained in these studies include various determents such as service quality, satisfaction, perceived value and trust. However, these studies employed e-service quality as a unidimensional concept which, in turn, resulted in limiting the practical implications. Thus, by investigating the critical role of each of the four dimensions of eTailQ to explain e-loyalty development, the current study can offer a more comprehensive and complete understanding of eTailQ in the research model.

Moreover, despite the wide recognition and popularity of the eTailQ scale, it has been subjected to various criticisms [32]. For instance, various studies have questioned its dimensionality, appropriateness and consistency [33]. Furthermore, the scale has been criticised for the limited attention given to the dimension of customer service [34]. More importantly, Connolly et al. [35] state that the majority of e-service quality scales, including eTailQ, were developed prior to the emergence of Web 2.0 technologies, and the wide penetration of social media technologies to e-commerce. As a result, the significant impact of social influence on the behaviour of consumers' online shopping has been overlooked. Accordingly, it is vital to modify the eTailQ scale to ensure that it can capture the unique 
aspects of Web 2.0 and social media on service quality. Integrating Web 2.0 technologies and social media platforms into e-commerce websites has resulted in the emergence of the concept of social commerce [36,37]. Shopping is perceived as a social activity, and social relationships have a significant impact on customers' purchase decisions. The eTailQ scale emphasises the need to evaluate the quality of the service platform, and to ignore the value rooted in the activities of social commerce (i.e., corporate social media), which has resulted in further criticism of the scale. Thus, this research aims to extend the eTailQ scale by incorporating the construct of social commerce components or electronic word-of-mouth (eWOM) as a key determinant of e-satisfaction and e-trust, and subsequently e-loyalty. eWOM is generally considered as any online negative/positive statement made by customers (former, actual, or potential) about a product/service or a firm. This research believes that eWOM is a fundamental element of e-service quality, as it is viewed as a credible and trustworthy source of information that can guide the process of online purchases. It is believed to be another dimension to signify the importance of customer service through accessing prior purchase information and the experiences of former customers to address e-service quality issues. Such access to valuable information and experiences can be significantly employed to assess customers' trust and reputation, and therefore loyalty towards a company. Furthermore, this study explores the indirect effect of reputation on e-loyalty through e-trust. Jordan, as a developing country, is viewed as a collectivist and high uncertainty avoidance culture. In such a culture, trust can be developed through a transference process. In such cultures where interpersonal ties and solidarity prevail, customers are inclined to consider others to be similar to themselves [38]. Accordingly, while an organization's trust is recognized as a critical proof source, it is more likely to transfer the organization's reputation to trust. Therefore, the main objectives of this paper as follows:

1. Extend the eTailQ scale to include social commerce components (SCC) as the fifth dimension of the scale, and empirically validate the proposed extension.

2. Examine the effects of each sub-dimension of the eTailQ scale (including the new dimension) as antecedents of e-trust and e-satisfaction, and subsequently e-loyalty.

3. Examine the role of reputation on the process of developing e-loyalty.

\section{Theoretical Foundation and Hypotheses Development}

The proposed model (see Figure 1) represents e-loyalty as the ultimate outcome of the research model. The research model suggests that e-loyalty is influenced directly by e-trust, e-satisfaction, and indirectly by reputation and eTailQ dimensions. This section will introduce the proposed hypotheses by first explaining: 1) the impact of e-trust, reputation. e-satisfaction on e-loyalty, and then 2) the influence of the eTailQ scale dimensions on e-trust, e-satisfaction and reputation. Figure 1 outlines the proposed model.

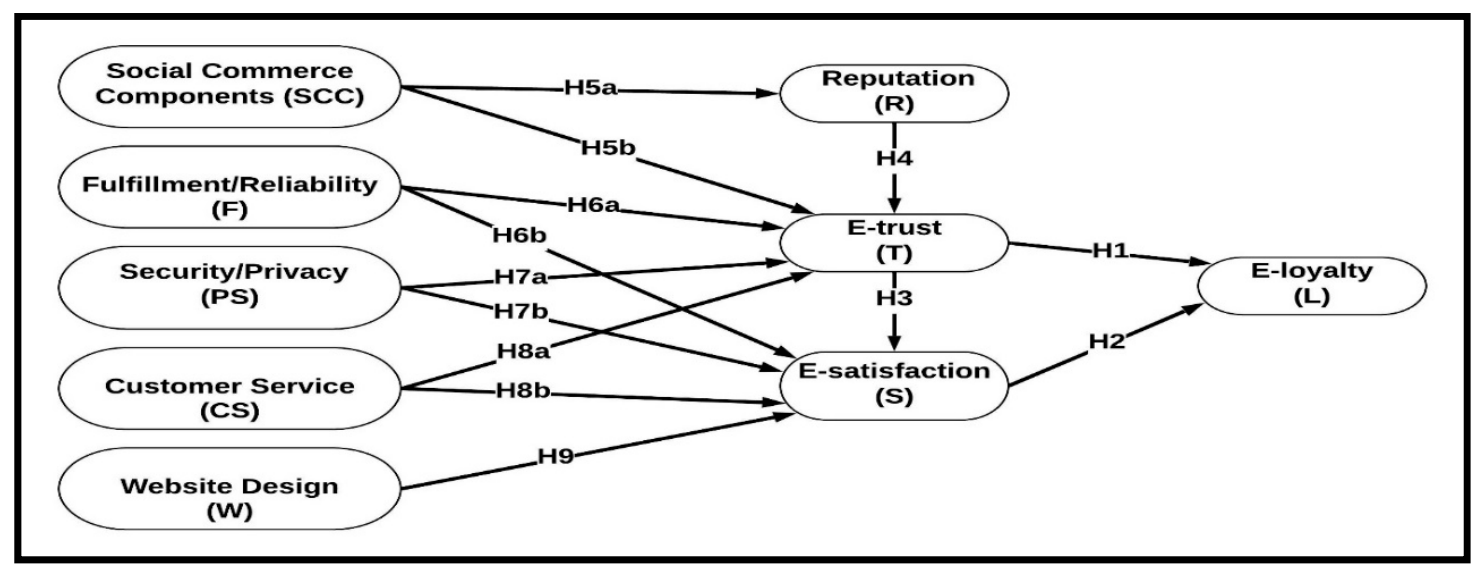

Figure 1. The research model. 


\subsection{E-Trust, Reputation, E-Satisfaction and E-Loyalty}

Trust can be transformed into loyalty, which will certainly drive the process of purchasing decision making $[16,18,39]$. In the digital environment, trust is referred to as "online trust" or "e-trust" and it has commonly been assumed that it is related to e-loyalty in the context e-commerce [13]. Accordingly, the relationship between e-trust and e-loyalty has been widely recognised in previous research due its importance in building customer relationships. Several studies confirm the direct positive influence of e-trust on e-loyalty $[40,41]$. Hou [42] points out that customer trust is critical for sustaining the success of an online business. According to Al-Adwan and Kokash [36] and Muhammad et al. [43], as uncertainty and risk are continually present in online purchasing, building e-customer confidence is important because the perception of both risk and uncertainty will impact on trust during transactions. Furthermore, it is noted that the most significant aspect for customers when selecting an online-vendor is trust [4]. Such an assumption stems from the fact that in the absence of face-to-face contact with an online business, customers are forced to seek reassurance. Hence, online businesses need to convince their customers that they can be trusted before starting to develop relationships with them.

\section{H1. "E-loyalty is positively influenced by e-trust".}

Customer satisfaction is vital for the sustainability of any business, and is indeed one of the major investigated areas as it supports businesses in their attempts to increase profitability and achieve excellence [1]. It has been argued by Kashif et al. [44] that satisfied customers are willing to retain a viable relationship with a company by constantly re-purchasing its services/products. Additionally, the process of retaining existing customers is less costly for businesses that prioritise customer satisfaction rather than attracting new customers [45]. Thus, the survival and profitability of organizations are heavily dependent on customer satisfaction. Customer satisfaction is viewed as a key outcome of a customer's assessment of overall purchasing and consumption experiences with regard to products/services [1]. It represents a comparison between purchasing and consumption expectations and experience [46]. Customer satisfaction is attained when a customer's experience (the final deliverable) meets or surpasses that customer's expectations [47].

The literature suggests that e-satisfaction and e-loyalty have a well-established relationship. This relationship stems from the traditional perspective, where a greater perception of customer satisfaction leads to an enhanced level of customer loyalty. In the context of e-commerce, the link between satisfaction and loyalty holds true, and is stronger in online environments due to the high levels of uncertainty and lack of physical communication [36]. Therefore, such a relationship has been frequently investigated in various studies [32,48]. Customer satisfaction is heavily dependent on customer experience while purchasing and consuming products or services. Having a delightful and memorable experience can significantly result in generating a positive attitude towards firms, and thus motivate customers to be loyal by engaging in repeated purchasing. In the meantime, it has been argued that satisfaction results in a higher degree of loyalty, but the existence of an embedded social network is necessary to ensure effective loyalty. $\mathrm{Li}$ et al. [49] conclude that a positive attitude towards the brand leads to a higher perception of loyalty, and subsequently will encourage customers to remain loyal. Additionally, the chance of converting customers into loyal customers is considerably greater if customers have a favourable attitude toward the brand.

\section{H2. "E-loyalty is positively influenced by e-satisfaction".}

In addition to its direct effect on e-loyalty, it is expected that e-trust will influence loyalty indirectly through e-satisfaction [18]. In fact, trust is a fundamental aspect for developing a reliable relationship between customer and seller. With regard to such a relationship, Polites et al. [50] stress that trust evaluation before a particular exchange or transaction is deemed to have a significant role to play in terms of customers' post-purchase satisfaction. Similarly, such an assumption holds true in online shopping, as trust is a vital component in initiating transactions. In the online shopping context, perceived risk is significantly higher than is the case with traditional shopping in terms of payment, 
delivery, and information exchange. Accordingly, customers are keen to transact with trustworthy e-retailers. Muhammad et al. [43] state that trust is necessary for satisfaction. Actually, online customers with high perceptions of trust when dealing with an e-retailer will be more satisfied and will be more committed to its services. Thus, this study arguers that the existence of e-satisfaction can be derived from the extent of customer e-trust.

H3. "E-satisfaction is influenced by e-trust".

In online retailing, a company's reputation is recognised as an important asset due to the inherent and high degree of uncertainty related to online trading transactions. Reputation is defined by Herbig and Milewicz [51] as "an estimation of the consistency over time of an attribute of an entity" (p. 18). They point out that an organisation can have various reputations with regard to different traits such as product quality, innovativeness, price and management quality. Furthermore, the relationship of retailers and customers is another attribute that can be utilised to bolster a company's reputation [52]. Reputation acts as a schema established from past direct transactions/experiences and/or reports/feedback from other customers. These can help build a foundation for consumer expectations of future experiences with the retailer [38]. Therefore, Liu et al. [53] point out that a company's reputation can be improved or damaged by the evaluation of what the company promises and what it truly delivers.

Additionally, it has been argued that losing a good reputation is easier than building it. In particular, the impact of negative actions is more intense than those of positive actions on consumer perception [54]. Thus, a good reputation results in a superior degree of customer satisfaction and trust, and thus companies with a good reputation are evaluated more positively than are companies with a poor reputation [55]. Specifically, if an e-retailer is perceived as fulfilling agreed conditions, obligations and promises, then customers will be inclined to believe that such behaviour will continue in the future. Various empirical studies confirm the critical role of reputation in developing customer trust as an increase in a company's reputation will lead to enhancement of such trust [38].

H4. "Reputation has a positive influence on e-trust".

\subsection{ETailQ Scale Dimensions, E-Trust, Reputation and E-Satisfaction}

E-service quality represents the overall perceptions of customers with respect to the quality of the service delivery of an online company. E-service quality has been referred to by Lee and Lin [56] as "evaluations and judgments regarding the excellence and quality of e-service delivery in the virtual market place" (p. 162). E-service quality scales have been employed in the literature to measure factors influencing a website's efficiency and effectiveness [57], measure a website's success [58] and evaluate customer e-satisfaction [59]. Parasuraman and Zeithhaml [60] have established a broad traditional service quality scale and entitled it SERVQUAL. Later, Parasuraman et al. [34] and Zeithaml et al. [57] have adopted the SERVQUAL scale and modified it to become e-SERVQUAL to fit the context of online service quality.

Several of e-service quality scales have been established in the literature. These scales have focused on diverse aspects and utilized different measurement items. For instance, Cristobal et al. [61] have developed a perceived e-service quality scale (PeSQ), a website quality scale (WebQualTM) [59], the eTail quality scale (eTailQ) [24] and a website quality scale (WebQual) [62]. These scales have been categorized into two main classes [61]: (1) online retailing services scales (such as e-SERVQUAL and eTailQ) in which online shopping is considered as a process that facilitates efficient and effective purchasing through service quality fulfilment, and (2) website design quality scales (such as WebQual), which focus on the perception of online shopping quality based on performance and aesthetics. The eTailQ scale developed by Wolfinbarger and Gilly [24] consists of four main elements: website design, fulfillment/reliability, privacy/security and customer service. Privacy/security represents the guarantee that the shopping behaviour data of customers are not shared or used by other parties, and the ability to ensure the security of customers' debit/credit card information. Website design reflects all aspects of customers' interactions with the website. This includes information search, navigation, order 
processing and suitable personalization. Customer service (or responsiveness) refers to the helpful, responsive, and supportive services that respond to customer queries rapidly. Reliability/fulfillment denotes the ability of a firm to provide an accurate display and description of products, so that customers receive the expected products they ordered. Additionally, reliability/fulfillment represents the capability to stock and deliver products to customers on time. For the purpose of this study, the eTailQ has been selected as the service quality scale because it considers both e-service quality dimensions and website interface measurements.

\subsubsection{Social Commerce Components}

Social commerce components in the study reflect any web 2.0 technology or feature on social media platforms that allow customers to share their purchase experiences as well as enable them to interact with e-retailers. Such concept is referred to "electronic-word-of-mouth (eWOM). Wu and Wang [63] defined eWOM as "oral person-to-person communication between a receiver and a sender, which involves a product, service, or brand" (p. 450). Many researchers have referred to eWOM as any negative or positive explanation regarding an experience by customers through online websites, for example reviews, recommendations and comments. When customers are uncertain about a purchase, they most likely will search for reliable and trustworthy sources to avoid any risks [64]. Customers' expectations are that these sources are referential and diagnostic. Information found on online shopping websites are not always considered reliable and trustworthy and are usually used by new customers [36,65]. Therefore, customers search for trustworthy eWOM and WOM [63], customers are easily influenced by WOM therefore appropriate efforts are given before making a purchasing decision when high levels of risks are perceived. Therefore, WOM information has a great effect on customers' purchasing decisions.

According to Zhang et al. [66], online shopping behaviour consists of two key phase. The first phase, costumers are worried and hesitant about the actual online purchase results and its transactions including receipt, payments and any perceived risk. The second phase, customers are confident and ready to revisit and/or repurchase products from a website they have previously used. Mosavi and Ghaedi [67] describe repurchase intentions as "the individual's judgements about buying a designated service again from the same company, considering his or her current situation and likely circumstances" (p. 4914). In marketing research, Gruen et al. [68], argue that a key indicator of customer loyalty is their intentions to repurchase. Likewise, the profits of businesses are found to be directly influenced by repurchase intentions [66]. Thus, it is suggested that customer loyalty with high retention is very important for e-commerce [69].

In this research eWOM is identified as a key factor that influences customer trust in e-commerce websites as in Hajli et al. [70]. Communicating online by giving opinions, feedback, comments, and recommendations regarding products or services can help other consumers in making purchase decisions without hesitation [71]. Most online customers value the opinions and experiences of previous online shoppers in determining their purchase and avoiding high degree of risk making eWOM essential to online customers. According to Matute et al. [72], reviews on e-commerce websites are crucial to potential customers. As they represent the opinions of previous experiences assuring trustworthiness and popularity of a websites' services and/or products.

H5a. "Reputation is positively influenced by social commerce components".

H5b. "E-trust is positively influenced by social commerce components".

\subsubsection{Fulfillment/Reliability}

Fulfillment/reliability is referred to by Wolfinbarger and Gilly [24] as "the accurate display and description of a product so that what customers receive is what they thought they ordered, and (b) delivery of the right product within the time frame promised" (p. 193). It is regarded as the capability of a retailer's website to deliver the exact product in the expected condition and at the expected time. 
Fulfillment/reliability has been discussed in the eTailQ scale based on two aspects. First, the product's description has to match the delivered product/service. It is vital that e-retailers provide sufficient information and descriptions about their products on their websites, particularly because customers are unable to physically evaluate real products prior to purchasing. Second, time delivery is another critical factor from the perspective of customers, because if there are repeated delays on delivery schedules, this may result in triggering a perception of unreliability towards an e-retailer's website. Several studies have concluded that fulfillment/reliability has a positive influence on e-satisfaction [30,73]. This study argues that fulfillment/reliability act as a source of comfort for customers as it confirms their expectations with regard to the process of purchasing, and subsequently generates preferable feelings and positive attitudes toward e-retailers' websites.

Furthermore, fulfillment/reliability is endorsed as an important factor when it comes to building online trust between customers and e-commerce websites. It requires that online retailers accurately display and designate products/services in a way that customers can receive what they expect from their orders. It also represents the capability to keep promises, stock products and deliver products/services on time. Online trust can be perceived by trustees (customers) as the integrity which reflects the ability of the trusted party (online retailers) to keep promises and to abide by rules of conduct [74]. Thus, building online trust is significantly influenced by the capability of online retailers to keep promises made, and on delivering the expected products/services on time to customers.

H6a. "Fulfilment/reliability of an e-retailer's website has positive influence on e-satisfaction".

H6b. "Fulfilment/reliability of an e-retailer's website has a positive influence on e-trust".

\subsubsection{Security/Privacy}

Risk perceptions related to e-commerce transactions in developing countries such as Jordan, are clearly present due to the existence of relatively insecure networks and servers in which the misuse of personal data and credit card information still poses a major threat. Since online customers and e-retailers cannot interact physically as in the offline business environment, the perception of uncertainty associated with online transactions is high [36]. Thus, privacy/security is recognized as a mechanism that can effectively reduce risk and uncertainty, while on the other hand it increases trust. Wolfinbarger and Gilly [24] state that security/privacy refers to the "security of credit card payments and privacy of shared information" (p. 193). The concepts of privacy and security are closely associated [75]. Legislators, customers and firms consider that both privacy and security concepts are closely related. Thus, these concepts have been conceptualized as one construct. Security is related to the ability of online retailers to provide adequate protection to the sensitive information of their customers from the risk of fraud and any possible financial losses [76]. On the other hand, privacy can be seen as a set of legal/ethical requirements and proper practices in terms of using and handling customers' information [77]. Various research into online shopping has declared that risk related to the loss of customers' security and privacy in the form of personal information, is considered as one of the key barriers to the adoption of e-commerce. Thus, Pavlou et al. [78] stress that customers' confidence must exist with regard to the willingness and ability of online retailers to secure personal and momentary information during transference and storage. Specifically, a guarantee of security acts as a fundamental factor in developing customers' trust with regard to purchasing from online retailers by decreasing customers' concerns with respect the abuse of personal data and the vulnerability of transmitted data. If customers have concerns with respect to the processes related to the collection and misuse of their personal information, then they tend not to trust online retailers [79]. Accordingly, customers are willing to share their personal information with online retailers if the perception of security is increased and assured to a level that meets their expectations.

This research proposes that the security/privacy of an e-commerce website has a direct influence on both e-trust and e-satisfaction. It has been proposed that security/ privacy has an indirect influence on e-satisfaction through e-trust [30]. They argue that establishing satisfaction will only come after the 
development of trust. The perception of high levels of risk with regard to retailers' websites in terms of e-payments and information exchange, make customers prefer to transact with online retailers they greatly trust. Confidence in exchanging personal information leads to building perceptions of reliability on the part of online retailers rather than having a pleasurable and favourable experience during online transactions. However, in this research, it is believed that a high level of security/privacy offered by an e-commerce website can lead to satisfying intensions which influences satisfaction behaviour.

H7a. "The perception of e-trust is increased by high levels of privacy/security".

H7b. "The perception of e-satisfaction is increased by high levels of privacy/security".

\subsubsection{Customer Service (Responsiveness)}

Wolfinbarger and Gilly [24] point out that customer service (or responsiveness) is defined as the "responsive, helpful, willing service that responds to customer inquiries quickly" (p. 193). Importantly, online customers' trust cannot be obtained only by low prices and decent ethics, but building online customers' trust is significantly influenced by both the effectiveness of customer services and the capability to deliver purchased products/services as promised [49]. Many scholars have confirmed the importance of customer service- (or responsiveness) related aspects on online customers' trust [80].

Online trust is linked with various aspects. These aspects include a timely response to customers' queries, communication with customers after purchasing to monitor and observe their satisfaction, offering customised care, giving customers the chance to track their purchases via the website, and clearly explaining how the private information of customers will be traded [49]. Other scholars [24,80] have highlighted the significance of customer service in developing online trust.

Furthermore, customer service is found to be an important factor in terms of customer satisfaction. When customers feel that a firm's staff are willing to offer a prompt service and to support them, then customers' perception of satisfaction is increased [81]. Effective and timely handling of customers' concerns and solving their problems through the website generate a sense of appreciation towards, and intimacy with, e-service providers (i.e., e-commerce websites) [82].

H8a. "The quality of customer support service has a positive influence on e-trust".

H8b. "E-satisfaction is positively influenced by the quality of customer support service".

\subsubsection{Website Design}

According to Wolfinbarger and Gilly [24], website design incorporates all components related to a customer's experience of dealing with a website, excluding customer service. These components include order processing, information search, product selection, negotiation and proper personalisation. There is a significant correlation between e-satisfaction and website design. In fact, it is hard to design a website or product that satisfies customers from various countries and cultures [83]. As a result, it is fundamental to determine the main factors that influence customer satisfaction. It is recognized that satisfaction is a key determinant for a system's success as it demonstrate the users' favourable attitudes and personal perceptions such as with regard to comfort and pleasure. Additionally, Zviran et al. [84] explain that customers' retention and their persistent use of a website is a critical issue for online retailers, because " ... websites have different hidden subjective factors that stem from the process of user and system interaction and affect overall user satisfaction, and that they can serve the development and maintenance phases of website creation" (p. 173). Thus, Evanschitzky et al. [85] define e-satisfaction as user positive perception of website design. Faisal et al. [83] reveals that different factors (i.e., content quality, navigation, interactivity) of website design have a substantial effect on customer satisfaction with regard to a website. Additionally, features such as being easy-to-navigate and usability are conceived as leading to a satisfying and pleasing shopping experience [86]. Moreover, Cai and Xu [87] confirm that a trouble-free website that increases the speed of order processing leads to an increased 
satisfaction with a website. Therefore, this research suggests that a proper design of online retailers' websites results in customer satisfaction. Website design is expected to have a positive influence on customer e-satisfaction but not on e-trust, because the features of a website that provide convenient information browsing and easy methods when it comes to placing orders are mainly associated with the transaction experience rather than the reliability and credibility of e-retailers' websites.

H9. "E-satisfaction is positively influenced by website design".

\section{Methodology}

The research model consisted of nine constructs that have been validated by previous research. In total, the questionnaire form included 29 items adopted from related research $[24,30,49,55]$, to measure the research model constructs (see Appendix A). The questionnaire form including the items of each construct is displayed in the appendices. A five-point Likert scale ranging from "strongly disagree" to "strongly agree" was employed to measure all items. All items were initially translated from English to Arabic by translation professors and experts. Afterwards, the items were translated back from Arabic into English in order to ensure consistency. The aim of the two-way translation process was to reduce construct, item and method biases. Additionally, corresponding to Ya-Wen et al. [88], the initial draft of the questionnaire form was pre-tested on 20 online shoppers for validity and readability of the questionnaire. Based on the feedback and comments obtained, a few items were amended and revised to increase understandability and clarity of the questions.

To meet the objectives of this study, individuals who had previously practiced online shopping in Jordan were selected as a unit of analysis. Thus, a screening question was presented at the beginning of the questionnaire to determine whether participants had experience with online shopping. Data was collected through two methods: an online survey and a paper-based survey. All participants were selected conveniently, as a link to the online survey was posted on several social media platforms (i.e., Facebook and Instagram) to invite users to participate. By clicking on the hyperlink, users were directed to the survey website. Additionally, the paper-based survey was distributed to both working people and students at two universities. Consequently, a total of 487 responses were obtained. Fourteen questionnaires were omitted because more than $40 \%$ of these questionnaires were incomplete (missing data). As a result, 473 responses qualified for data analysis. Table 1 demonstrates the participants' demographics.

The test of Harman's single factor was performed to assess the existence of Common Method Variance (CMV) [89]. The result demonstrated that the highest variance explained by a single factor was $42.3 \%$. Consequently, not a single factor in isolation can explain the majority of variance in the dataset. Additionally, following the recommendation of Malhotra et al. [90], to ensure the absence of $\mathrm{CMV}$, all items in the data were modelled as indicators of a single factor. According to Hair et al. [91], the fitness indices were weak. The results indicate that the root mean square error of approximation (RMSEA) was $0.94(>0.08)$, and the goodness of fit index (GFI) was $0.86(<0.9)$. Thus, it can be concluded that CMV was not present in the dataset for this research. 
Table 1. Participants' demographics.

\begin{tabular}{cccc}
\hline Demographic & Range & Frequency & $\mathbf{\%}$ \\
\hline \multirow{3}{*}{ Age } & $<20$ & 107 & 23 \\
& $20-29$ & 236 & 50 \\
& $30-39$ & 93 & 20 \\
& $>40$ & 37 & 7 \\
\hline \multirow{2}{*}{ Gender } & Male & 265 & 56 \\
& Female & 208 & 44 \\
\hline \multirow{3}{*}{ Occupation } & Student & 109 & 23 \\
& Employed & 317 & 67 \\
& Un-employed & 47 & 10 \\
\hline \multirow{3}{*}{ Education } & Graduate & 244 & 52 \\
& Undergraduate & 102 & 21 \\
& Postgraduate & 90 & 19 \\
& High School & 29 & 6 \\
& Other & 8 & 2 \\
\hline \multirow{3}{*}{ E-commerce experience } & $<6$ months & 201 & 42 \\
& 6-12 months & 169 & 36 \\
& $>12$ months & 103 & 22 \\
\hline
\end{tabular}

\section{Data Analysis}

A Structure Equation Modelling (SEM) approach was utilized to analyse the dataset. Data analysis was conducted by using SmartPLS3 software. The approach of Henseler et al. [92] was followed who suggest that data analysis is carried out within two sequential steps: measurement model and structural model. In phase one, the measurement model aims to ensure the reliability and validity of the research model's items and constructs. This stage will be carried out in two sub-stages: (1) measurement model for first-order constructs and (2) measurement model for second-order constructs. On the other hand, the structural model was performed to evaluate the proposed hypotheses (paths).

\subsection{Measurement Model for First-Order Constructs}

Explanatory factor analysis (EFA) was first conducted to classify the dataset into several key components. EFA analysis began by evaluating the suitability of performing factor analysis for the dataset. The suitability evaluation was based on two constraints: (1) Kaiser-Mayer-Olkin sampling adequacy test (KMO's test) and (2) Bartlett's Test of Sphericity (Bartlett's test). The coefficient of the KMO test was 0.87, which is in line with the general criteria of Pallant [93] while the value of the Bartlett test was $7023.6(p<0.001)$. Therefore, it can be confirmed that the null hypothesis is rejected.

Afterwards, principal component analysis was performed to extract each item in the dataset with factor loading $\geq 0.4$ and eigenvalues $\geq 1$ [94]. As can be demonstrated in the factor load matrix (Table 2) after varimax rotation, a nine factor solution with 29 items accounting for $88.5 \%$ of the overall variance, and also the values of factor loadings of the 29 items corresponding to their theoretical factor were $>0.7$, indicating acceptable interpretability of common factors.

Then, confirmatory factor analysis (CFA) was performed to measure the reliability and validity of the dataset. In terms of reliability, Cronbach's Alpha $(\alpha)$ coefficient of each construct was assessed to ensure the internal consistency, which reflects the internal correlations between each construct's items. A value of 0.7 for Cronbach's Alpha $(\alpha)$ is considered an acceptable coefficient [91]. As can be demonstrated in Table 3, all constructs substantially acquired an acceptable internal consistency as all values of $\alpha$ exceeded the cut-off value of 0.7 . 
Table 2. Explanatory factor analysis results.

\begin{tabular}{|c|c|c|c|c|c|c|c|c|c|c|}
\hline \multirow{2}{*}{ Construct } & \multirow{2}{*}{ Item } & \multicolumn{9}{|c|}{ Component } \\
\hline & & $\mathbf{1}$ & 2 & 3 & 4 & 5 & 6 & 7 & 8 & 9 \\
\hline \multirow{4}{*}{$\begin{array}{l}\text { Social Commerce Components } \\
\text { (Ewom) (SCC) }\end{array}$} & SCC1 & 0.85 & & & & & & & & \\
\hline & SCC2 & 0.84 & & & & & & & & \\
\hline & SCC3 & 0.81 & & & & & & & & \\
\hline & SCC4 & 0.77 & & & & & & & & \\
\hline \multirow{4}{*}{ E-loyalty (L) } & L1 & & 0.83 & & & & & & & \\
\hline & L2 & & 0.81 & & & & & & & \\
\hline & L3 & & 0.79 & & & & & & & \\
\hline & L4 & & 0.76 & & & & & & & \\
\hline \multirow{3}{*}{ Reputation (R) } & R1 & & & 0.91 & & & & & & \\
\hline & $\mathrm{R} 2$ & & & 0.89 & & & & & & \\
\hline & R3 & & & 0.88 & & & & & & \\
\hline \multirow{3}{*}{ E-satisfaction (S) } & S1 & & & & 0.89 & & & & & \\
\hline & $\mathrm{S} 2$ & & & & 0.88 & & & & & \\
\hline & S3 & & & & 0.84 & & & & & \\
\hline \multirow{3}{*}{$\begin{array}{c}\text { Customer Service } \\
\text { (Responsiveness) (CS) }\end{array}$} & CS1 & & & & & 0.85 & & & & \\
\hline & CS2 & & & & & 0.81 & & & & \\
\hline & CS3 & & & & & 0.79 & & & & \\
\hline \multirow{3}{*}{ Fulfilment/Reliability (F) } & F1 & & & & & & 0.82 & & & \\
\hline & F2 & & & & & & 0.81 & & & \\
\hline & F3 & & & & & & 0.80 & & & \\
\hline \multirow{3}{*}{ Website Design (W) } & W1 & & & & & & & 0.86 & & \\
\hline & W2 & & & & & & & 0.82 & & \\
\hline & W3 & & & & & & & 0.73 & & \\
\hline \multirow{3}{*}{ Security/Privacy (SP) } & SP1 & & & & & & & & 0.87 & \\
\hline & SP2 & & & & & & & & 0.83 & \\
\hline & SP3 & & & & & & & & 0.78 & \\
\hline \multirow{3}{*}{ E-trust (T) } & T3 & & & & & & & & & 0.81 \\
\hline & $\mathrm{T} 2$ & & & & & & & & & 0.76 \\
\hline & $\mathrm{T} 1$ & & & & & & & & & 0.77 \\
\hline
\end{tabular}

"Extraction Method: Principal Component Analysis"; "Rotation Method: Varimax with Kaiser Normalization".

Table 3. Confirmatory factor analysis results.

\begin{tabular}{|c|c|c|c|c|c|}
\hline Construct & Item & Loading & ${ }^{*} \alpha$ & ${ }^{*}$ AVE & ${ }^{*} \mathrm{CR}$ \\
\hline \multirow{4}{*}{ E-loyalty (L) } & L1 & 0.96 & \multirow{4}{*}{0.94} & \multirow{4}{*}{0.86} & \multirow{4}{*}{0.96} \\
\hline & L2 & 0.93 & & & \\
\hline & L3 & 0.92 & & & \\
\hline & L4 & 0.90 & & & \\
\hline \multirow{3}{*}{ E-trust (T) } & T1 & 0.91 & \multirow{3}{*}{0.88} & \multirow{3}{*}{0.81} & \multirow{3}{*}{0.92} \\
\hline & $\mathrm{T} 2$ & 0.90 & & & \\
\hline & T3 & 0.88 & & & \\
\hline \multirow{3}{*}{ E-satisfaction (S) } & S1 & 0.98 & \multirow{3}{*}{0.97} & \multirow{3}{*}{0.94} & \multirow{3}{*}{0.98} \\
\hline & S2 & 0.97 & & & \\
\hline & S3 & 0.95 & & & \\
\hline \multirow{3}{*}{ Fulfilment/Reliability (F) } & F1 & 0.96 & \multirow{3}{*}{0.95} & \multirow{3}{*}{0.90} & \multirow{3}{*}{0.96} \\
\hline & F2 & 0.95 & & & \\
\hline & F3 & 0.94 & & & \\
\hline \multirow{3}{*}{$\begin{array}{c}\text { Customer Service } \\
\text { (Responsiveness) (CS) }\end{array}$} & CS1 & 0.96 & \multirow{3}{*}{0.93} & \multirow{3}{*}{0.87} & \multirow{3}{*}{0.95} \\
\hline & CS2 & 0.94 & & & \\
\hline & CS3 & 0.91 & & & \\
\hline \multirow{3}{*}{ Website Design (W) } & W1 & 0.95 & \multirow{3}{*}{0.92} & \multirow{3}{*}{0.86} & \multirow{3}{*}{0.95} \\
\hline & W2 & 0.94 & & & \\
\hline & W3 & 0.89 & & & \\
\hline \multirow{3}{*}{ Security/Privacy (SP) } & SP1 & 0.92 & \multirow{3}{*}{0.86} & \multirow{3}{*}{0.78} & \multirow{3}{*}{0.92} \\
\hline & SP2 & 0.89 & & & \\
\hline & SP3 & 0.84 & & & \\
\hline \multirow{3}{*}{ Reputation (R) } & R1 & 0.98 & \multirow{3}{*}{0.97} & \multirow{3}{*}{0.95} & \\
\hline & R2 & 0.97 & & & 0.98 \\
\hline & R3 & 0.96 & & & \\
\hline & SCC1 & 0.96 & & & \\
\hline Social Commerce Components & SCC2 & 0.93 & & & \\
\hline$(\mathrm{eWOM})(\mathrm{SCC})$ & SCC3 & 0.92 & 0.94 & 0.86 & 0.96 \\
\hline & SCC4 & 0.91 & & & \\
\hline
\end{tabular}

“* $\alpha$ : Cronbach's Alpha, CR: Composite Reliability, AVE: Average Variance Extracted”. 
With regard to the validity, two tests of validity were performed: convergent and discriminant validities. These tests were performed to ensure that each construct's items are strongly correlated, and to ensure there is appropriate distinction between various factors [95]. Following the criterion of Fornell-Larcker [96] and the rules of thumb of Hair et al. [91], convergent validity is achieved when the value of Average Variance Extracted (AVE) is $>0.5$, standardized factor loading of all items is $>0.707$, and composite reliability (CR) is $>0.7$. In contrast, discriminant validity requires the squared root of AVE of each construct to be greater than the correlation estimates between constructs, and the correlation between any two constructs $<0.85$ [97]. As shown in Table 3, the factor loadings of each item were above 0.707 , the values of AVE of each construct were $\geq 0.5$, and the coefficients of CR were 0,7 . Table 4 demonstrates that the $\sqrt{ }$ AVE of each construct were greater than the correlations between constructs. Additionally, the "heterotrait-monotrait ratio of correlations (HTMT)" test was performed to ensure the presence of discriminant validity. The results demonstrate that all HTMT estimates passed the threshold of 0.85 as all estimates were below 0.85 [97], ensuring the presence of discriminant validity.

Table 4. Discriminant validity and collinearoty results.

\begin{tabular}{|c|c|c|c|c|c|c|c|c|c|c|}
\hline Construct & AVE & CR & $F$ & $\mathbf{L}$ & $\mathbf{R}$ & $\mathrm{S}$ & SP & SCC & $T$ & $\bar{W}$ \\
\hline CR & 0.87 & ${ }^{*} 0.93$ & & & & & & & & \\
\hline $\mathrm{F}$ & 0.90 & $* * 0.49$ & 0.94 & & & & & & & \\
\hline $\mathrm{L}$ & 0.86 & 0.48 & 0.58 & 0.92 & & & & & & \\
\hline $\mathrm{R}$ & 0.95 & 0.43 & 0.38 & 0.41 & 0.97 & & & & & \\
\hline S & 0.94 & 0.45 & 0.49 & 0.55 & 0.28 & 0.96 & & & & \\
\hline SP & 0.78 & 0.53 & 0.51 & 0.47 & 0.53 & 0.34 & 0.88 & & & \\
\hline SCC & 0.86 & 0.49 & 0.49 & 0.58 & 0.46 & 0.43 & 0.45 & 0.92 & & \\
\hline $\mathrm{T}$ & 0.81 & 0.54 & 0.55 & 0.58 & 0.48 & 0.45 & 0.59 & 0.52 & 0.90 & \\
\hline W & 0.86 & 0.48 & 0.53 & 0.54 & 0.33 & 0.56 & 0.35 & 0.54 & 0.43 & 0.92 \\
\hline
\end{tabular}

\subsection{Measurement Model for Second-Order Construct}

The first objective of this study was to provide empirical evidence that validates the extension of the eTailQ scale to include social commerce components (SCC) as the fifth sub-dimension of the scale. The scale originally consists of four dimensions, namely: fulfilment/reliability (F), security/privacy (SP), website design (W) and customer service (CS). Therefore, in order to address this objective, as recommended by Thornton et al. [98], eTailQ scale is treated as a second-order formative construct with five first-order (sub-constructs) reflective constructs, namely: social commerce components (SCC), fulfilment/reliability (F), security/privacy (SP), website design (W), and customer service (CS).

The structure of a higher-order construct should be evaluated in a similar manner to a lower-order construct [99]. Subsequently, reliability, convergent and discriminant validity were examined again against acceptable cut-off values. Thus, a separate confirmatory factor analysis (CFA) was performed again to validate the second-order construct (eTailQ). The results of this stage indicate that website design $(\mathrm{W})(\beta=0.76, t$-value $=85, p$-value $<0.0001)$, security /privacy $(\mathrm{SP})(\beta=0.71, t$-value $=64$, $p$-value $<0.0001)$, fulfilment/reliability (f) $(\beta=0.78, t$-value $=110, p$-value $<0.0001)$, customer service (CS) $(\beta=0.77, t$-value $=103, p$-value $<0.0001)$ and social commerce components (SCC) $(\beta=0.81$, $t$-value $=120.1, p$-value $<0.0001$ ) had significant loadings in eTailQ scale (see Figure 2 ). 


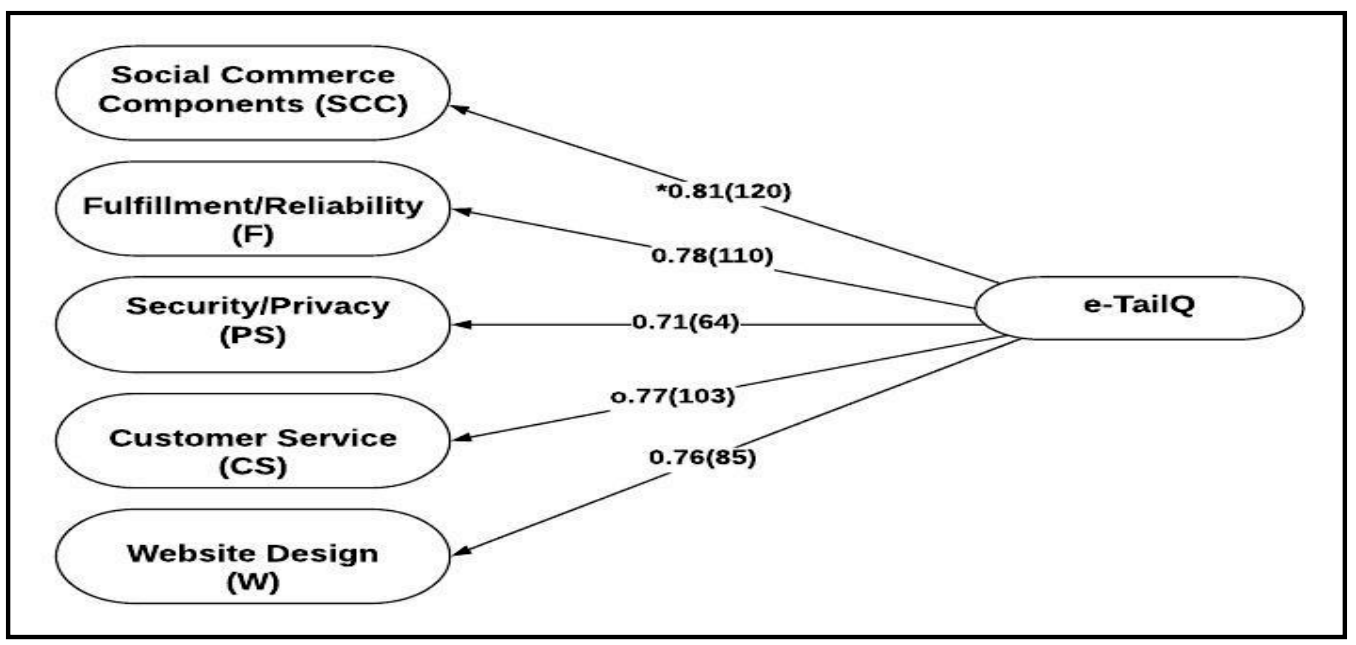

Figure 2. Second-order construct validation;*: path coefficient, ( ): $t$-value

Additionally, the AVE of eTailQ was 0.69. As Table 5 demonstrates, discriminant validity of e-TailQ was supported as the squared root of the AVE values were greater than any correlation between constructs. Furthermore, collinearity was evaluated by the means of variance of inflation factor (VIF). All VIF values for all constructs were $<5$, indicating the absence of multicollinearity [100]. All estimates of website design (W), security /privacy (SP), fulfilment/reliability (F), customer service (CS) and social commerce components (SCC) were acceptable (see Table 6). Overall, the results confirm the distinct nature of the five first-order constructs. Although CS, F, SP, SCC and W correlate highly with eTailQ, VIF coefficients show that these sub-constructs are discernible into five distinct constructs.

Table 5. Discriminant validity and VIF for second order construct.

\begin{tabular}{ccccccccc}
\hline Construct & AVE & eTailQ & CS & F & SP & SCC & W & VIF \\
\hline eTailQ & 0.69 & ${ }^{*} \mathbf{0 . 8 3}$ & & & & & & - \\
CS & 0.87 & $* * 0.76$ & $\mathbf{0 . 9 3}$ & & & & & 1.71 \\
F & 0.9 & 0.78 & 0.48 & $\mathbf{0 . 9 4}$ & & & & 1.75 \\
SP & 0.78 & 0.71 & 0.53 & 0.51 & $\mathbf{0 . 8 8}$ & & & 1.62 \\
SCC & 0.86 & 0.80 & 0.48 & 0.48 & 0.45 & $\mathbf{0 . 9 2}$ & & 1.68 \\
W & 0.86 & 0.75 & 0.48 & 0.53 & 0.35 & 0.54 & $\mathbf{0 . 9 2}$ & 1.72 \\
\hline \multicolumn{7}{c}{ * $\sqrt{\text { AVE value for each construct, }}{ }^{* *}$ correlation between constructs. }
\end{tabular}

Table 6. Convergent validity for second-order construct.

\begin{tabular}{|c|c|c|c|c|c|}
\hline Construct & Item & Loading & ${ }^{*} \alpha$ & ${ }^{*} \mathrm{AVE}$ & ${ }^{*} \mathrm{CR}$ \\
\hline \multirow{3}{*}{ Fulfilment/Reliability (F) } & F1 & 0.96 & \multirow{3}{*}{0.95} & \multirow{3}{*}{0.90} & \multirow{3}{*}{0.96} \\
\hline & F2 & 0.95 & & & \\
\hline & F3 & 0.93 & & & \\
\hline \multirow{3}{*}{$\begin{array}{c}\text { Customer Service } \\
\text { (Responsiveness) (CS) }\end{array}$} & CS1 & 0.96 & \multirow{3}{*}{0.92} & \multirow{3}{*}{0.87} & \multirow{3}{*}{0.95} \\
\hline & $\mathrm{CS} 2$ & 0.93 & & & \\
\hline & CS3 & 0.92 & & & \\
\hline \multirow{3}{*}{ Website Design (W) } & W1 & 0.96 & \multirow{3}{*}{0.92} & \multirow{3}{*}{0.86} & \multirow{3}{*}{0.95} \\
\hline & W2 & 0.95 & & & \\
\hline & W3 & 0.88 & & & \\
\hline \multirow{3}{*}{ Security/Privacy (SP) } & SP1 & 0.93 & \multirow{3}{*}{0.86} & \multirow{3}{*}{0.78} & \multirow{3}{*}{0.92} \\
\hline & SP2 & 0.89 & & & \\
\hline & SP3 & 0.84 & & & \\
\hline \multirow{4}{*}{$\begin{array}{l}\text { Social Commerce Components } \\
\text { (Ewom) (SCC) }\end{array}$} & SCC1 & 0.95 & \multirow{4}{*}{0.94} & \multirow{4}{*}{0.86} & \multirow{4}{*}{0.96} \\
\hline & SCC2 & 0.93 & & & \\
\hline & SCC 3 & 0.92 & & & \\
\hline & SCC4 & 0.91 & & & \\
\hline
\end{tabular}


Table 6. Cont.

\begin{tabular}{cccccc}
\hline Construct & Item & Loading & ${ }^{*} \alpha$ & ${ }^{*}$ AVE & ${ }^{*}$ CR \\
\hline ET1 & 0.93 & & & \\
ET2 & 0.88 & & \\
ET3 & 0.87 & & \\
ET4 & 0.74 & & \\
ET5 & 0.83 & & \\
ET6 & 0.73 & & \\
eTailQ scale (ET) & ET7 & 0.82 & & & \\
& ET8 & 0.79 & & & \\
& ET9 & 0.75 & 0.92 & 0.69 & 0.97 \\
& ET10 & 0.76 & & & \\
& ET11 & 0.79 & & & \\
& ET12 & 0.81 & & & \\
& ET13 & 0.84 & & & \\
& ET14 & 0.87 & & & \\
& ET15 & 0.89 & & & \\
& ET16 & 0.91 & & & \\
\hline
\end{tabular}

“* $\alpha$ : Cronbach's Alpha, CR: Composite Reliability, AVE: Average Variance Extracted".

This suggests that the five sub-constructs contribute considerably to the primary construct of the eTailQ scale, with social commerce components (SCC) being the most vital contributor.

\subsection{Structural Model}

The second and third objectives of this study were to examine the effects of eTailQ dimensions and reputation on e-trust and e-satisfaction. This stage aimed to examine the proposed paths in the research model outlined in Figure 1. Three main elements should be assessed, namely: the amount of variance explained (R2), beta coefficient and corresponding $t$-values [101]. Thus, the proposed model and its suggested paths (hypotheses) were built by SmartPLS3 software. A bootstrapping procedure with a resample of 5000 was performed to obtain the above mentioned elements. However, it was important to examine the performance of the proposed model before proceeding to examine the proposed paths. Accordingly, the indices of goodness of fit (GoF) were evaluated.

Specifically, the indices of "Standardized Root Mean Square Residual (SRMR), Normed Fit Index (NFI)", and the statistical test of (bootstrapped based) inferences of the discrepancy including: the unweighted least squares (dULS) and geodesic (dG) discrepancies [102]. The results indicate that the value of SRMR was $0.031(<0.08)$, and NFI was $0.969(>0.9)$, which represent an acceptable fit [91]. Moreover, the test of discrepancies show that the "dULS < bootstrapped HI 95\% of dULS and $\mathrm{dG}<$ bootstrapped $\mathrm{HI} 95 \%$ of $\mathrm{dG}$ ". Such estimates indicate that the proposed model acquired a good fitness.

As illustrated in Figure 3, e-trust (T) $(\beta=0.42, t=21.3)$ and e-satisfaction $(\mathrm{S})(\beta=0.36, t=21.1)$ had positive direct effects on e-loyalty (L). Both e-trust and e-satisfaction explained $44 \%$ of the variance $(\mathrm{R} 2=0.44)$ in e-loyalty. Social commerce components $(\mathrm{SCC})(\beta=0.16, t=8.4)$, reputation $(\mathrm{R})(\beta=0.12$, $t=7.5)$, fulfilment/reliability (F) $(\beta=0.21, t=10.6)$, security/privacy (SP) $(\beta=0.25, t=14.7)$ and customer service (CS) $(\beta=0.18, t=7.5)$ had direct positive effects on e-trust (T), explaining $50 \%$ of e-trust $(\mathrm{R} 2=0.5)$. 


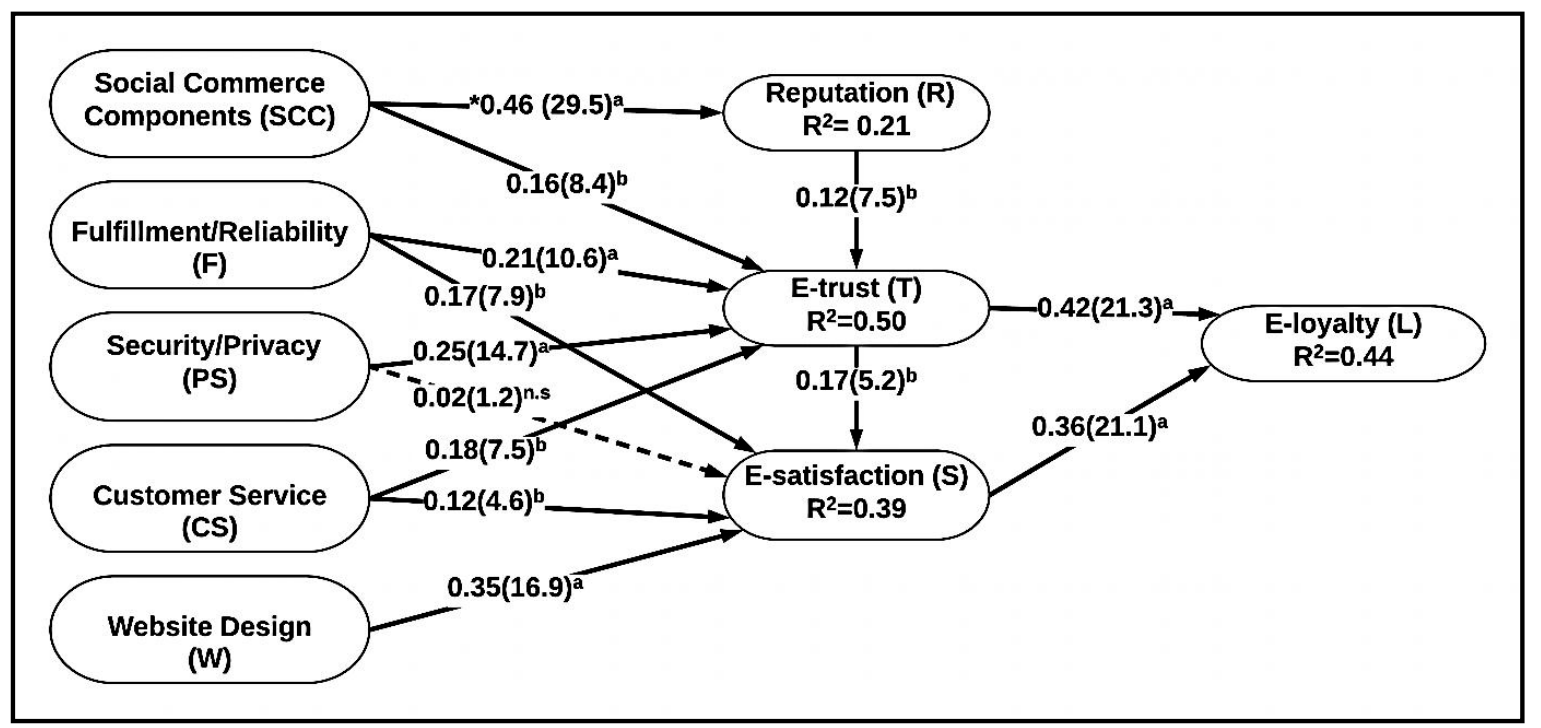

Figure 3. Structural model results; ${ }^{\prime *}$ : path coefficient, a: $p<0.001, \mathrm{~b}: p<0.01$, ( ): $t$-value, n.s: insignificant".

Furthermore, e-trust (T) $(\beta=0.17, t=5.2, p$-value $<0.01)$, fulfilment/reliability $(\mathrm{F})(\beta=0.17, t=5.2$, $p$-value $=0.01)$, customer service (CS) $(\beta=0.18, t=7.5)$ and website design $(\mathrm{W})(\beta=0.35, t=16.9)$ had direct positive effects on e-satisfaction (S), explaining $39 \%$ of the variance in e-satisfaction $(R 2=0.39)$. Surprisingly, security/privacy (SP) $(\beta=0.02, t=1.2, p$-value $>0.05)$ had an insignificant effect on e-satisfaction (S). Finally, social commerce components (SCC) $(\beta=0.46, t=29.5)$ had a direct positive effect on reputation $(\mathrm{R})$, explaining $21 \%$ of the variance in reputation $(\mathrm{R} 2=0.21)$. Table 7 summarizes the results of examining the proposed hypotheses.

Table 7. Summary of Hypotheses testing.

\begin{tabular}{|c|c|c|c|}
\hline Path & Coefficient $(\beta)$ & $t$-Value & Result \\
\hline "E-trust $\rightarrow$ e-loyalty" & 0.42 & 21.3 & supported \\
\hline "E-satisfaction $\rightarrow$ e-loyalty" & 0.36 & 21.1 & supported \\
\hline "E-trust $\rightarrow$ e-satisfaction" & 0.17 & 5.2 & supported \\
\hline "Reputation $\rightarrow$ e-trust" & 0.12 & 7.5 & supported \\
\hline "Social Commerce Components $\rightarrow$ reputation" & 0.46 & 29.5 & supported \\
\hline "Social Commerce Components $\rightarrow$ e-trust" & 0.16 & 8.4 & supported \\
\hline “Fulfilment/Reliability $\rightarrow$ e-trust" & 0.21 & 10.6 & supported \\
\hline "Fulfilment/Reliability $\rightarrow$ e-satisfaction" & 0.17 & 7.9 & supported \\
\hline "Security/Privacy $\rightarrow$ e-trust" & 0.25 & 14.7 & supported \\
\hline "Security/Privacy $\rightarrow$ e-satisfaction" & 0.02 & 1.2 & Rejected \\
\hline "Customer Service $\rightarrow$ e-trust" & 0.18 & 7.5 & supported \\
\hline "Customer Service $\rightarrow$ e-satisfaction" & 0.12 & 4.6 & supported \\
\hline "Website Design $\rightarrow$ e-satisfaction" & 0.3 .5 & 16.9 & supported \\
\hline
\end{tabular}

\subsection{Mediation}

A Sobel test (1982) was conducted to examine whether e-satisfaction and e-trust act as mediators that carry the effects of the independent variables to the dependant variable (e-loyalty). As Table 8 indicates, all indirect effects of the independent variables through e-trust to e-loyalty were significant. Such results designate that enhancing customers' perceptions of reputation, fulfilment/reliability, social commerce components security/privacy and customer service would significantly boost e-trust and subsequently increase e-loyalty. In contrast, e-satisfaction carries the effects of fulfilment/reliability, customer service and website design to e-loyalty. All these indirect effects through e-satisfaction to e-loyalty were significant. Thus, an increase in customers' perception of fulfilment/reliability, 
customer service and website design would significantly enhance their e-satisfaction and in turn lead to greater e-loyalty. The only insignificant indirect effect on e-loyalty was the effect of security/privacy through e-satisfaction. This refers to the fact that security/privacy had an insignificant direct effect on e-satisfaction (the mediator).

Table 8. Mediation results.

\begin{tabular}{cccccc}
\hline Independent Construct & Mediator & $\begin{array}{c}\text { Dependent } \\
\text { Construct }\end{array}$ & T-Statistic & $p$-Value & Result \\
\hline Reputation & e-trust & e-loyalty & 12 & $p<0.0001$ & significant \\
social commerce components & e-trust & e-loyalty & 7.5 & $p<0.0001$ & significant \\
fulfilment/reliability & e-trust & e-loyalty & 9.6 & $p<0.0001$ & significant \\
fulfilment/reliability & e-satisfaction & e-loyalty & 7.5 & $p<0.0001$ & significant \\
Security/Privacy & e-trust & e-loyalty & 11.9 & $p<0.0001$ & significant \\
Security/Privacy & e-satisfaction & e-loyalty & 1.2 & $p>0.08$ & insignificant \\
customer service & e-trust & e-loyalty & 7.1 & $p<0.0001$ & significant \\
customer service & e-satisfaction & e-loyalty & 4.4 & $p<0.0001$ & significant \\
website design & e-satisfaction & e-loyalty & 12.7 & $p<0.0001$ & significant \\
\hline
\end{tabular}

\section{Discussion}

E-trust and e-satisfaction are found to influence e-loyalty both in parallel and sequentially. Similar to [103] and [104], e-satisfaction is found to have a significant positive influence on e-loyalty. Such results indicate that when customers are satisfied with a particular e-commerce website, then they develop a favourable response (purchase or repurchase). Subsequently, this results in increasing customers' loyalty towards an e-retailer's website. E-trust is also found to have a positive and significant impact on e-loyalty. While this finding is evidently confirmed by $[105,106]$, the result is inconsistent with Eid [13] who found e-trust has an insignificant influence on e-loyalty. The more an e-retailer's portal is perceived to be trustworthy, the more likely customers will be loyal and frequently transact with the portal. Furthermore, e-trust not only has a direct impact on e-loyalty, but also has an indirect influence on e-loyalty through e-satisfaction. Consistent with [18,107], e-trust has a significant direct influence on e-satisfaction. The findings confirm that e-trust is a major determinant of e-satisfaction. E-trust in an online shopping environment can be an effective factor in maintaining long-term relationships between customers and service providers. High perceptions of e-trust can considerably diminish the high level of uncertainty related to an online environment and motivate customers to transact online with service providers. In contrast, customers are unlikely to perform transactions through a website which is unable to provide a sense of trust.

E-trust acts as mediator between reputation and e-loyalty. In line with prior research $[55,108,109]$, the results confirm that reputation is recognized as a fundamental aspect that effects e-trust. Reputation has a positive significant impact on e-trust. This indicates that the better an e-retailer's reputation, the higher customers' e-trust in the retailer. In online shopping, it is hard for customers to determine e-retailers' benevolence (e-retailer's unwillingness to exploit the vulnerability of customers) [38]. Thus, e-trust is concerned with customers' confidence and belief that promises made by e-retailers can be reliable (i.e., credibility). An e-retailer with a considerable reputation is expected to be unwilling to risk e-trust by failing to deliver promises and fulfil obligations. Because e-retailers with a good reputation highly perceive untrustworthy behaviour forbidden, customers are keen to trust e-retailers with a good reputation over those with poor reputation.

Additionally, e-trust and e-satisfaction are also found to mediate the relationships between eTailQ service dimensions and e-loyalty. In agreement with [5] and [13], security/privacy has a significant positive influence on e-trust. This indicates that the more customers' confidence in e-retailers to protect their personal and financial information increases, the more customers will trust and share such information, and conduct transactions with the e-retailer. Such findings stress that data security/privacy assurance is deemed to be a crucial factor in constructing e-trust. E-trust in an e-retailer may be 
weighted significantly based on customers' concerns with respect to the misuse of their monetary and personal information. Thus, the safeguarding of personal and financial information throughout an online transaction and in storage is one of the key factors that help e-retailers grow and continue in the market. While security/ privacy is found as a key factor that influences e-trust, security/privacy is found to be a weak antecedent of e-satisfaction. The insignificant influence of security/privacy on e-satisfaction is in agreement with $[5,13,80]$, and inconsistent with $[73,110]$. Such findings may refer to the fact that customers lack the experience to directly judge the security/privacy of an e-commerce website. Moreover, in light of increasing confidence in online transactions, customers have begun to recognise security/privacy as a spontaneous characteristic.

The findings also offer sufficient evidence to suggest that website design has a significant role in the process of developing customers' e-satisfaction. Such a finding is in agreement with $[30,80]$, but inconsistent with [47]. Empirical evidence has demonstrated that the quality of website design is vital in building e-satisfaction. The quality of website design represents the physical reflection of e-retailers' competences in enabling effortless usage of their websites. Characteristics of website design (i.e., navigation, interface, website content) are important for the customer to have a joyful and favourable shopping experience. Customers' perception of e-satisfaction is increased when they perceive an e-commerce website design as intuitive, visually appealing, with a clear layout, usable, easy to navigate, easy to interact with, and the provision of quality and easy to access information.

In line with [80] but in contrast to [30], customer service (or responsiveness) has a positive influence on both e-trust and e-satisfaction. Customer service is considered as a convincing procedure offered by an e-retailer to online customers to solve or address any potential issues or problems. Online customers expect e-retailers to respond to their enquires promptly. In online shopping, customer service signifies the importance of prompt response and timely assistance to customers. Ali et al. (2017) explain that online customers need a speedy response to their enquiries, and therefore decent responsiveness may significantly influence customers' satisfaction. Additionally, it represents the desire to effectively and timely address customers' requests and enquires with any issue or concerns they may encounter, especially during and after purchasing. A response in a timely manner and support to customers leads to a decrease in uncertainty and increases perceived convenience, and therefore increases satisfaction and trust.

Consistent with [5], fulfilment/reliability has positive influence on e-trust and e-satisfaction. Offline fulfilment represents the closing loop of a product/receiver purchase in the online scenario, and therefore positive influences on trust and satisfaction were anticipated. In online shopping, customers cannot directly (face-to-face) interact with e-retailers, and they cannot physically evaluate and examine products. Thus, customers need to be assured that their purchased products will be received as expected. In the context of online retailing, e-retailers pick-up products that customers have ordered. Customers may be concerned with not receiving the exact products that they have ordered. Additionally, customers fear that products can be damaged while shipping. Consequently, it is critical to ensure the delivery of the right products, in the promised condition, within the expected time frame.

Social commerce components (or eWOM) are found to have a positive influence on e-trust. Such a result confirms the findings of previous studies [111,112]. Additionally, similar to [113], social commerce components (or eWOM) have a positive impact on reputation. This demonstrates that the more customers have access to former customers' purchase experience, the more potential/actual customers will trust e-retailers and subsequently increase their reputation. EWOM (i.e., social media, reviews, forums, recommendation systems) is viewed as a trustworthy source of information for customers. Social commerce components (or eWOM) represent methods of online communication and information exchange about products/services and e-retailers, between receivers (potential or actual customers) and senders (former customers). To the receivers, the senders of information have no commercial intent, which therefore makes such information more credible when compared to e-retailers' website information and other commercial channels such as advertisements. EWOM, 
through social commerce components, allows customers to have various channels to provide and share their purchase experience about products/services and e-retailers without any interruption.

According to Al-Adwan and Kokash [36], customers tend to trust information acquired from other customers on social commerce components (i.e., reviews, feedback, comments on social media) because such acquired information is recognised as independent and protected from e-retailers' interference. Thus, customers are allowed to explore the previous experience of former customers with products/services which allows them to evaluate the trustworthiness of e-retailers regarding any issues with respect to e-service quality. Additionally, the act of allowing customers to freely share their experiences about purchased products/services and interaction is recognised as a trustworthy behaviour from e-retailers. This is because such behaviour shows that e-retailers have high transparency, refrain from hiding information and avoid any untrustworthy and opportunistic behaviour against customers [37]. As result, this scenario significantly increases customers' e-trust in e-retailers. In addition, eWOM can be seen and used as an effective tool for customer service, especially in terms of the complaint resolution process. Fruitful negotiation and problem solving through such components (i.e., Facebook) may allow customers to have a positive perception and experience due to feelings of being respected, as e-retailers has provided sufficient attention to solve a problem. Such feelings and satisfaction subsequently motivate customers to spread and share positive information concerning e-retailers with peers, friends and communities via social media platforms and other Web 2.0 technologies. As a result, sharing and spreading positive information increases e-retailers' reputation and encourages the purchase potential of online customers.

\section{Theoretical and Practical Implications}

From a theoretical standpoint, the eTailQ scale has been extensively criticised due to the absence of social influence on online shopping. The scale was developed before the emergence of Web 2.0 technologies and the increased use of social media in e-commerce. Hence, this study fills this gap by extending the eTailQ scale to include the social aspect of e-commerce as an important dimension of e-service quality. Specifically, it presents social commerce components (or eWOM) as a new dimension to the eTailQ scale. The study provided empirical evidence that confirms the validity of the extended scale. Nowadays, online customers' expectations and demands are high and require e-retailers to develop various strategies that enhance the quality of e-service provided to customers. This study offered an empirically tested and conceptually derived measurement model specification for the eTailQ scale. It confirms the distinct dimensions of the eTailQ scale that should be used as strategy of sensing opportunities in developing e-loyalty. Extending the eTailQ scale will offer future investigations a foundation to discover various strategic patterns of developing e-trust and e-satisfaction, and subsequently e-loyalty in different contexts.

From managerial and practical perspectives, it is important to note that e-loyalty relies on both e-trust and e-satisfaction, and the determinants of these two constructs are different. This study investigated the role of each dimensions of the extended eTailQ scale separately on e-satisfaction and e-trust. This would offer useful managerial and practical implications, as online businesses operating in the digital space will benefit from a clear framework that describes how they can identify opportunities of developing e-loyalty embedded in their relationships with customers, which will aid them to communicate responsively and interact effectively with their customers in the digital space.

Besides its direct influence on e-loyalty, e-trust has an indirect influence on e-loyalty through e-satisfaction. Such a finding supports prior notions of the key role of e-trust in building e-loyalty. Online transactions are by their nature associated with perceptions of high risk, and trust is viewed to be a fundamental element in reducing perceptions of high risk. As a result, e-retailers should recognise that to develop both e-loyalty and e-satisfaction, there is the necessary prior foundation of e-trust.

Social commerce is recognised as the newest form of e-commerce that supports and facilitates the social aspect of online shopping experiences. The main characteristics that influence online social commerce are significantly different from the characteristics of traditional e-commerce websites. Thus, 
this research identifies social commerce components-CCS (or eWOM) as a new aspect of e-service quality. It has an indirect and positive influence on e-loyalty. This indirect influence is generated through e-trust and e-satisfaction. SCC acts as one of the key predictors of customers' e-trust and e-satisfaction. Such a finding suggests that a well-designed e-commerce website should include numerous features and tools of Web 2.0 technologies (i.e., reviews, ratings, recommendations systems, forums, etc.) and it should be connected to social networking platforms (i.e., Facebook, Instagram, etc.). Such technologies and connections to social media platforms can significantly deliver customers a sense of sociability during the entire experience with the website. Specifically, in order to enhance customers' e-trust and e-satisfaction with an e-commerce website, it is critical to incorporate various Web 2.0 technologies within e-commerce websites, and connect these websites to different social network platforms. In doing so, customers can access more reliable and social information that has been generated from former customers' experiences and feedback about specific products and e-retailers. Such practice would lead to the reduction of customers' perception of uncertainty by offering them a trustworthy source of information other than the website of e-retailers. Furthermore, this action would increase the reliability of e-retailers as it is an important indication of transparency and deters the hiding of information from customers.

This research also demonstrates that security/privacy is a fundamental aspect of e-service quality that indirectly influences e-loyalty through e-trust. This result shows that the positive perception of security/privacy by customers is associated with high perceptions of e-trust, which in turn leads to enhanced e-loyalty. Subsequently, e-retailers should be aware that it is important for customers to have a safe experience during the use of their website. For instance, effective policies and statements of security/privacy procedures should be clearly developed, explained and stated. More importantly, since customers' sensitive, personal and financial information will be exchanged during online transactions, it is fundamental to secure such information by employing certified security/privacy programs and solutions. For example, the management of e-commerce websites should rely on professional, trusted and well-established third party providers (i.e., PayPal) to guarantee secure e-payments. Such actions can decrease customer anxiety with respect to fulfilment and security.

Website design is highlighted as another key factor in e-service quality that indirectly influences e-loyalty through e-satisfaction. This study demonstrates the design of an e-commerce website correlates significantly with customers' satisfaction. Designers and developers of e-commerce websites should take into account that when website design is considered tangible cues can be used to boost customers' e-satisfaction. Satisfied customers need a usable, simple and intuitive user interface design that displays information in a clear manner. Additionally, a high quality website design guarantees user-friendly with aspects such as quick and easy sign in/up, searching with minimum clicks, customised search options and speedy access to the web. Such features decrease the cost, time and effort associated with searching, processing and using information. Additionally, the management of e-commerce websites are advised to carry out constant online surveys that allow customers to express their interaction and experience with the website, and therefore perform informed and effective site improvements.

The results also empirically confirm the reputation-trust link. The findings suggest that reputation has an indirect impact on e-loyalty through e-trust. The increased use of an e-commerce website can significantly enhance customers' e-trust and subsequently their e-loyalty. It has been argued that building an online reputation is not an easy task for e-retailers (especially for solely online retailers compared to multi-channel retailers), as customer have limited signals compared to what they have in traditional physical stores. Accordingly, practitioners should centre their efforts on increasing the reputation of their services/products and enhance customer satisfaction in order to compete strongly by encouraging customers to share and exchange eWOM. As a result, e-retailers should be involved in friendly communications with customers to increase e-trust and therefore e-loyalty. Additionally, e-retailers can incorporate trust and reputation systems into their websites to evaluate the credibility of the current state and information of their reputation. 
The findings suggest that customer service (responsiveness) has direct and positive influences on e-trust and e-satisfaction. Customers involved in online shopping need fast feedback on their questions and enquiries, and they expect e-retailers to respond to their enquiries and questions instantly. Thus, e-retailers should put more effort into providing customers with accurate and error-free information and appropriate solutions in a prompt manner, especially when customers have questions or problems. It is noteworthy to mention that e-retailers should realise that some aspects of responsiveness are related to the functionality of websites. For example, the functionality of e-commerce websites should provide instant service, helpful and clear guidance when a problem occurs, and offer accurate information about when the ordered service will be actioned, or the ordered products delivered. Such actions can lead to customer satisfaction by keeping them informed about all aspects related their ordered products/services, and to trust that e-retailers are easily contactable and available immediately for effective help in addressing issues.

Fulfilment/Reliability has positive direct effects on e-loyalty and e-satisfaction. This finding values the importance of performing services or delivering products on time and as ordered. In other words, customers expect to receive the exact quantity and quality of products/services they ordered within the time schedule promised by e-retailers, and they also expect to be charged correctly by e-retailers. Accordingly, e-retailers should keep their promises in terms of delivering the right quality and quantity of products or implementing the right services on time. Competition is high in the digital space and e-retailers should distinguish their products/services from others by offering moral competence and reliable performance. E-retailers should adopt practices that can reliably expose the honesty of services/products to customers and encourage positive customer perceptions towards e-retailers, which subsequently will enhance e-trust and e-satisfaction. For example, applying free delivery, full return and refund policies may result in a positive effect on consumer e-satisfaction and e-trust.

\section{Conclusions, Limitations and Future Work}

The objectives of this study were to extend the scale of eTailQ, and to examine the effects of extending the scale on e-trust and e-satisfaction. In addition, it investigated the role of reputation in the process of developing e-loyalty. This study suggested that social commerce components as a new dimension of the eTailQ scale have a fundamental role in constructing e-loyalty. The empirical and statistical evidence provided in this study showed that the construct of social commerce components is a necessity in complementing the quality dimensions of e-service in the environment of e-commerce. Specifically, the dramatic increase of using Web 2.0 technologies and social media platforms by customers to inform their purchasing decisions, means that social commerce components for e-commerce websites can be an effective tool in increasing service quality via various means (reliable information, customer service, responsiveness etc). In addition, the findings found that reputation has a critical role in developing e-trust and e-satisfaction, and subsequently e-loyalty. This signifies the vital need for e-retailers to represent themselves in a way that gains customers' trust and satisfaction. This representation should include all online and offline processes and functions.

This study has a few limitations that future studies could fulfil. According to Parasuraman et al. [34], the scale e-service quality focuses on two key aspects: (1) the quality of electronic service (e-SERV-QUAL), and (2) the quality of electronic recovery service (e-REC-S-QUAL). In this study the e-REC-S-QUAL was neglected as the focus was only on e-SERV-QUAL. All participants of this study were general online customers without identifying whether or not they experienced problems during their previous online transactions. In order to investigate e-REC-S-QUAL, further studies should determine and include only participants who had problems during their transactions. Furthermore, further studies are required to explore additional antecedents of customer loyalty that can help e-retailers increase online customer loyalty. As suggested by Al Adwan [114], this can be done by conducting a mixed methods approach to unveil comprehensive variables that can significantly contribute in enhancing e-loyalty. 
Author Contributions: M.A.A.-H. was responsible for the following parts: conceptualization of the framework, project administration, visualization, funding acquisition and resources. On the other hand, A.S.A.-A. had several responsibilities include: writing - original draft preparation, methodology development, formal analysis, validation, investigation, data curation, writing - review and editing and overall supervision.

Funding: This research was funded by Al Ahliyya Amman University, Amman, Jordan.

Acknowledgments: We would like to thankfully acknowledge the assistance and support of the faculty members of the departments of Electronic Business \& Commerce, and Management Information Systems at Al-Ahliyya Amman University for providing insightful feedback.

Conflicts of Interest: The authors declare no conflict of interest. Additionally, we declare that the funders had no role in the design of the study; in the collection, analyses, or interpretation of data; in the writing of the manuscript, or in the decision to publish the results.

\section{Appendix A}

Table A1. The questionnaire form.

\begin{tabular}{|c|c|}
\hline Construct & Item Description \\
\hline E-loyalty (L) & $\begin{array}{l}\text { L1: "When I need to make a purchase, this website is my first choice". } \\
\text { L2: "I believe this is my favorite website to buy the same kind of product". } \\
\text { L3: "To me, this website is the best retail website to do business with" } \\
\text { L4: "As long as the present service continues, I doubt that I would switch to another website". }\end{array}$ \\
\hline E-trust (T) & $\begin{array}{l}\text { T1: "I trust what this online retailer says about its products". } \\
\text { T2: "This online retailer is reliable". } \\
\text { T3: "I trust the claims and promises this website makes about a product". }\end{array}$ \\
\hline E-satisfaction (S) & $\begin{array}{l}\text { S1: "I am satisfied with the product of this online retailer". } \\
\text { S2: "I am overall satisfied with this online retailer". } \\
\text { S3: "I am satisfied with the purchase experience at this online retailer". }\end{array}$ \\
\hline $\begin{array}{l}\text { Fulfilment/Reliability } \\
\text { (F) }\end{array}$ & $\begin{array}{l}\text { F1: "The product was represented accurately by the website". } \\
\text { F2: "The product is delivered on time as promised by the company". } \\
\text { F3: "I get what I ordered from the website". }\end{array}$ \\
\hline $\begin{array}{c}\text { Customer Service } \\
\text { (Responsiveness) (CS) }\end{array}$ & $\begin{array}{l}\text { CS1: "This website is willing and ready to respond to customers' needs". } \\
\text { CS2: "Inquiries are answered promptly". } \\
\text { CS3: "When you have a problem, this website shows a sincere interest in solving it". }\end{array}$ \\
\hline Website Design (W) & $\begin{array}{l}\text { W1: "This website is well designed in order not to waste my time". } \\
\text { W2: "This website provides in-depth information". } \\
\text { W3: "It is quick and easy to complete a transaction on this website". }\end{array}$ \\
\hline Security/Privacy (SP) & $\begin{array}{l}\text { SP1: "This website has adequate security features". } \\
\text { SP2: "I feel safe in my transactions with this website". } \\
\text { SP3: "I feel my privacy is protected on this website". }\end{array}$ \\
\hline Reputation (R) & $\begin{array}{l}\text { R1: "This e-commerce website is well known". } \\
\text { R2: "This e-commerce website has a good reputation". } \\
\text { R3: "I am familiar with the name of this e-commerce website". }\end{array}$ \\
\hline $\begin{array}{l}\text { Social Commerce } \\
\text { Components (eWOM) } \\
\text { (SCC) }\end{array}$ & $\begin{array}{l}\text { SCC1: "I usually use people rating and reviews about products on the internet". } \\
\text { SCC2: "I usually use people's recommendations to buy a product on the internet". } \\
\text { SCC3: "I use online forums and online communities for acquiring information about a product". } \\
\text { SCC4: "Overall, I find that my participation to social networks is useful for my purchase of the } \\
\text { company's products/services". }\end{array}$ \\
\hline
\end{tabular}

\section{References}

1. Moriuchi, E.; Takahashi, I. Satisfaction trust and loyalty of repeat online consumer within the Japanese online supermarket trade. Australas. Mark. J. (AMJ) 2016, 24, 146-156. [CrossRef]

2. Anderson, R.; Srinivasan, S. E-Satisfaction and E-Loyalty: A Contingency Framework. Psychol. Mark. 2003, 20, 123-138. [CrossRef]

3. Flavián, C.; Guinalíu, M.; Gurrea, R. The role played by perceived usability, satisfaction and consumer trust on website loyalty. Inf. Manag. 2006, 43, 1-14. [CrossRef]

4. Reichheld, F.; Schefter, P. Online customer loyalty: Your Secret Weapon on the Web. Harv. Bus. Rev. 2000, 78, 105-113.

5. Husain, S. The Determinants of Loyalty in Online Commerce - An Exploratory Study in India. Electron. J. Inf. Syst. Dev. Ctries. 2017, 81, 1-17. [CrossRef]

6. Gefen, D. Customer Loyalty in E-Commerce. J. Assoc. Inf. Syst. 2002, 3, 27-51. [CrossRef] 
7. Schmitt, P.; Skiera, B.; Bulte, C. Do Referral Programs Increase Profits. GfK Mark. Intell. Rev. 2013, 5, 8-11. [CrossRef]

8. Coltman, T.; Devinney, T.; Midgley, D. Customer Relationship Manag. and Firm Performance. J. Inf. Technol. 2009, 26, 205-219. [CrossRef]

9. Srinivasan, S.; Anderson, R.; Ponnavolu, K. Customer loyalty in e-commerce: An exploration of its antecedents and consequences. J. Retail. 2002, 78, 41-50. [CrossRef]

10. Shankar, V.; Smith, A.; Rangaswamy, A. Customer satisfaction and loyalty in online and offline environments. Int. J. Res. Mark. 2003, 20, 153-175. [CrossRef]

11. Van-Riel, A.; Liljander, V.; Jurriëns, P. Exploring consumer evaluations of e-services: A portal site. Int. J. Serv. Ind. Manag. 2001, 12, 359-377. [CrossRef]

12. Alam, S.; Yasin, N. An Investigation into the Antecedents of Customer Satisfaction of Online Shopping. J. Mark. Dev. Compet. 2010, 5, 71-78.

13. Eid, M. Determinants of e-commerce customer satisfaction, trust, and loyalty in Saudi Arabia. J. Electron. Commer. Res. 2011, 12, 78-93.

14. Parra-Lopez, E.; Martínez-González, J.; Chinea-Martin, A. Drivers of the formation of e-loyalty towards tourism destinations. Eur. J. Manag. Bus. Econ. 2018, 27, 66-82. [CrossRef]

15. Pratminingsih, S.; Lipuringtyas, C.; Rimenta, T. Factors Influencing Customer Loyalty Toward Online Shopping. Int. J. Trade Econ. Financ. 2013, 4, 104-110. [CrossRef]

16. Brilliant, M.; Achyar, A. The Impact of Satisfaction and Trust on Loyalty of E-Commerce Customers. ASEAN Mark. J. 2013, 5, 51-58. [CrossRef]

17. Sarwar, M.; Abbasi, K.; Pervaiz, S. The effect of customer trust on customer loyalty and customer retention: A moderating role of cause related marketing. Glob. J. Manag. Bus. Res. 2012, 12, $27-36$.

18. Ziaullah, M.; Feng, Y.; Akhter, S. E-Loyalty: The influence of product quality and delivery services on e-trust and e-satisfaction in China. Int. J. Adv. Res. Technol. 2014, 10, 20-31.

19. Santouridis, I. E-Service quality and its impact on customer satisfaction and trust: An empirical study on Greek customers of Internet shops. In Proceedings of the 6th International Conference on Enterprise Systems, Accounting and Logistics, Hessaloniki, Greece, 18-19 May 2009; pp. 17-31.

20. Lin, H.; Wang, Y. An examination of the determinants of customer loyalty in mobile commerce contexts. Inf. Manag. 2006, 43, 271-282. [CrossRef]

21. McKnight, D.; Chervany, N. What Trust Means in E-Commerce Customer Relationships: An Interdisciplinary Conceptual Typology. Int. J. Electron. Commer. 2001, 6, 35-59. [CrossRef]

22. Ribbink, D.; van Riel, A.; Liljander, V.; Streukens, S. Comfort your online customer: Quality, trust and loyalty on the internet. Manag. Serv. Qual. Int. J. 2004, 14, 446-456. [CrossRef]

23. Ismail, M.; Safa, N. Trust, Satisfaction, and Loyalty Formation in Electronic Commerce. J. Ind. Intell. Inf. 2014, 2, 228-232. [CrossRef]

24. Wolfinbarger, M.; Gilly, M. eTailQ: Dimensionalizing, measuring and predicting etail quality. J. Retail. 2003, 79, 183-198. [CrossRef]

25. Tsai, S. E-loyalty driven by website quality: The case of destination marketing organization websites. J. Organ. Comput. Electron. Commer. 2017, 27, 262-279. [CrossRef]

26. Yang, X.; Yuan, Q. The Effects of B2C Interaction on Customer Loyalty. J. Data Inf. Sci. 2018, 3, 78-104. [CrossRef]

27. Zhou, R.; Wang, X.; Shi, Y.; Zhang, R.; Zhang, L.; Guo, H. Measuring e-service quality and its importance to customer satisfaction and loyalty: An empirical study in a telecom setting. Electron. Commer. Res. 2018, 19, 477-499. [CrossRef]

28. Cyr, D. Modeling Web Site Design Across Cultures: Relationships to Trust, Satisfaction, and E-Loyalty. J. Manag. Inf. Syst. 2008, 24, 47-72. [CrossRef]

29. Winnie, P. The impact of trustworthiness and customer e-loyalty and e-satisfaction. Int. J. Acad. Res. Bus. Soc. Sci. 2014, 4, 390-408. [CrossRef]

30. Kim, J.; Jin, B.; Swinney, J. The role of etail quality, e-satisfaction and e-trust in online loyalty development process. J. Retail. Consum. Serv. 2009, 16, 239-247. [CrossRef]

31. Chang, H.; Wang, H. The Relationships Among E-Service Quality, Value, Satisfaction and Loyalty in Online Shopping. In E-European Advances in Consumer Research Volume 8; Borghini, S., McGrath, M., Otnes, C., Eds.; Association for Consumer Research: Duluth, MN, USA, 2007; pp. 10-14. 
32. Ahmad, A.; Rahman, O.; Khan, M. Consumer's Perception of Website Service Quality: An Empirical Study. J. Internet Commer. 2016, 15, 125-141. [CrossRef]

33. Connolly, R.; Bannister, F.; Kearney, A. Government website service quality: A study of the Irish revenue online service. Eur. J. Inf. Syst. 2010, 19, 649-667. [CrossRef]

34. Parasuraman, A.; Zeithaml, V.; Malhotra, A. E-S-QUAL. J. Serv. Res. 2005, 7, 213-233. [CrossRef]

35. Connolly, R.; Scott, M.; Delone, W. Corporate Social Media: Understanding the Impact of Service Quality \& Social Value on Customer Behavior. J. Soc. Media Soc. 2016, 8, 44-73.

36. Al-Adwan, A.; Kokash, H. The Driving Forces of Facebook Social Commerce. J. Theor. Appl. Electron. Commer. Res. 2019, 14, 15-32. [CrossRef]

37. Al-Adwan, A. Novel research framework for social commerce purchase intention. J. Theor. Appl. Inf. Technol. 2018, 96, 4390-4404.

38. Jin, B.; Park, J.Y.; Kim, J. Cross-cultural examination of the relationships among firm reputation, e-satisfaction, e-trust, and e-loyalty. Int. Mark. Rev. 2008, 25, 324-337. [CrossRef]

39. Al-Adwan, A.; Alrousan, M.; Al-Soud, A.; Al-Yaseen, H. Revealing the Black Box of Shifting from Electronic Commerce to Mobile Commerce: The Case of Jordan. J. Theor. Appl. Electron. Commer. Res. 2019, 14, 51-67. [CrossRef]

40. Sevim, N. The Effect of E-service Quality, E-trust and E-satisfaction on Formation Online Customer Loyalty. Bus. Manag. Stud. Int. J. 2018, 6, 107-127.

41. Zhu, S.; Kuo, J.; Munkhbold, E. Effects of e-customer satisfaction and e-trust on e-loyalty: Mongolian online shopping behavior. In Proceedings of the 5th IIAI International Congress on Advanced Applied Informatics (IIAI-AAI), Kumamoto, Japan, 10-14 July 2016; pp. 847-852.

42. Hou, Y. Service Quality of Online Apparel Retailers and Its Impact on Customer Satisfaction, Customer Trust and Customer Loyalty. Ph.D. Thesis, The University of North Carolina at Greensboro, Greensboro, Guilford, 2005.

43. Muhammad, M.; Muhammad, M.; Suhaimi, M.; Hussin, H.; Razi, M.; Abdullah, K. Building trust in e-commerce from an Islamic perspective: A literature review. Am. Acad. Sch. Res. J. 2013, 5, 161-168.

44. Kashif, M.; Shukran, S.; Rehman, M.; Sarifuddin, S. Customer satisfaction and loyalty in Malaysian Islamic banks: A PAKSERV investigation. Int. J. Bank Mark. 2015, 33, 23-40. [CrossRef]

45. Yousuf, K. The Impact of Service Quality on Customer Satisfaction in Banking Sector of Karachi. J. Manag. Bus. Econ. 2017, 12, 15-28.

46. Khristianto, W.; Kertahadi, I.; Suyadi, I. The influence of information, system and service on customer satisfaction and loyalty in online shopping. Int. J. Acad. Res. 2012, 4, 28-32.

47. Ludin, I.; Cheng, B. Factors Influencing Customer Satisfaction and E-Loyalty: Online Shopping Environment among the Young Adults. Manag. Dyn. Knowl. Econ. 2014, 2, 462-471.

48. Kaur, M.; Kaur, R. E-Service Quality: Foundation of Customer Loyalty. MERC Glob. Int. J. Soc. Sci. Manag. 2018, 5, 87-90.

49. Li, H.; Tevrizci, C.; Ahma-Anyanwu, N. An Empirical Study of E-Loyalty development Process from the E-Service Quality Experience: Testing the Etaliq Scale. In Proceedings of the Pacific Asia Conference on information Systems PACIS, Chengdu, China, 24-28 June 2014; p. 51.

50. Polites, G.; Williams, C.; Karahanna, E.; Seligman, L. A Theoretical Framework for Consumer E-Satisfaction and Site Stickiness: An Evaluation in the Context of Online Hotel Reservations. J. Organ. Comput. Electron. Commer. 2012, 22, 1-37. [CrossRef]

51. Herbig, P.; Milewicz, J. The relationship of reputation and credibility to brand success. J. Consum. Mark. 1993, 10, 18-24. [CrossRef]

52. Li, T.; Berens, G.; de Maertelaere, M. Corporate Twitter Channels: The Impact of Engagement and Informedness on Corporate Reputation. Int. J. Electron. Commer. 2013, 18, 97-126. [CrossRef]

53. Liu, S.; Yu, H.; Miao, C.; Kot, A. A fuzzy logic based reputation model against unfair ratings. In Proceedings of the International Conference on Autonomous Agents and Multi-Agent Systems, Saint Paul, MN, USA, 6-10 May 2013; pp. 821-828.

54. Morgan-Thomas, A.; Veloutsou, C. Beyond technology acceptance: Brand relationships and online brand experience. J. Bus. Res. 2013, 66, 21-27. [CrossRef]

55. Liu, D.; Guo, X. Can trust and social benefit really help? Empirical examination of purchase intentions for wearable devices. Inf. Dev. 2016, 33, 43-56. [CrossRef] 
56. Lee, G.; Lin, H. Customer perceptions of e-service quality in online shopping. Int. J. Retail Distrib. Manag. 2005, 33, 161-176. [CrossRef]

57. Zeithaml, V.; Parasuraman, A.; Malhotra, A. Service quality delivery through web sites: A critical review of extant knowledge. J. Acad. Mark. Sci. 2002, 30, 362-375. [CrossRef]

58. Liu, C.; Arnett, K. Exploring the factors associated with Web site success in the context of electronic commerce. Inf. Manag. 2000, 38, 23-33. [CrossRef]

59. Loiacono, E.; Watson, R. Webqual (tm): A Web Site Quality Instrument. 2000. Available online: https: //dl.acm.org/citation.cfm?id=931839 (accessed on 24 June 2019).

60. Zeithaml, V.A.; Parasuraman, A.; Malhotra, A. An Empirical Examination of the Service Quality-Value-Loyalty Chain in an Electronic Channel; University of North Caroline: Chapel Hill, NC, USA, 2002.

61. Cristobal, E.; Flavián, C.; Guinalíu, M. Perceived e-service quality (PeSQ). Manag. Serv. Qual. Int. J. 2007, 17, 317-340. [CrossRef]

62. Barnes, S.; Vidgen, R. An integrative approach to the assessment of e-commerce quality. J. Electron. Commer. Res. 2002, 3, 114-127.

63. Wu, P.; Wang, Y. The influences of electronic word-of-mouth message appeal and message source credibility on brand attitude. Asia Pac. J. Mark. Logist. 2011, 23, 448-472. [CrossRef]

64. Wangenheim, F.; Bayon, T. The effect of word of mouth on services switching: Measurement and moderating variables. Eur. J. Mark. 2004, 38, 1173-1185. [CrossRef]

65. Al-Adwan, A. Revealing the influential factors driving social commerce adoption. Interdiscip. J. Inf. Knowl. Manag. 2019, 14, 295-324.

66. Zhang, Y.; Fang, Y.; Wei, K.; Ramsey, E.; McCole, P.; Chen, H. Repurchase intention in B2C e- commerce-A relationship quality perspective. Inf. Manag. 2011, 48, 192-200. [CrossRef]

67. Mosavi, A.; Ghaedi, M. Role of perceived value in explaining trust and repurchase intention in e-shopping. Afr. J. Bus. Manag. 2012, 6, 4910-4920.

68. Gruen, T.; Osmonbekov, T.; Czaplewski, A. EWOM: The impact of C2C online knowhow exchange on customer value and loyalty. J. Bus. Res. 2006, 59, 449-456. [CrossRef]

69. Hellier, P.; Geursen, G.; Carr, R.; Rickard, J. Customer repurchase intention: A general structural equation model. Eur. J. Mark. 2003, 37, 1762-1800. [CrossRef]

70. Hajli, M.; Hajli, M.; Khani, F. Establishing trust in social commerce through social word of mouth. In Proceedings of the 7th International Conference on e-Commerce in Developing Countries: With Focus on e-Security (ECDC), Kish Island, Iran, 17 April 2013; pp. 1-22.

71. Cheung, C.; Lee, M. Online Consumer Reviews: Does Negative Electronic Word-of-Mouth Hurt More? In Proceedings of the AMCIS 2008, Toronto, ON, Canada, 14-17 August 2008; p. 143.

72. Matute, J.; Polo-Redondo, Y.; Utrillas, A. The influence of EWOM characteristics on online repurchase intention: Mediating roles of trust and perceived usefulness. Online Inf. Rev. 2016, 40, 1090-1110. [CrossRef]

73. Ting, O.; Ariff, M.; Zakuan, N.; Sulaiman, Z.; Saman, M. E-Service Quality, E-Satisfaction and E-Loyalty of Online Shoppers in Business to Consumer Market; Evidence form Malaysia. In Proceedings of the 4th International Conference on Manufacturing, Optimization, Industrial and Material Engineering (MOIME 2016), Bali, Indonesia, 19-20 March 2016; p. 012012.

74. Hu, X.; Wu, G.; Wu, Y.; Zhang, H. The effects of Web assurance seals on consumers' initial trust in an online vendor: A functional perspective. Decis. Support Syst. 2010, 48, 407-418. [CrossRef]

75. Toufaily, E.; Arcand, M.; Legault, J.; Ricard, L. The Roles of Website Characteristics and Social Network Communities in Developing Customer E-loyalty in the Online Travel Industry. J. Tour. Hosp. 2016, 5, 1-11.

76. Zhou, M.; Tian, D. An Integrated Model of Influential Antecedents of Online Shopping Initial Trust: Empirical Evidence in a Low-Trust Environment. J. Int. Consum. Mark. 2010, 22, 147-167. [CrossRef]

77. Casaló, L.; Flavián, C.; Guinalíu, M. The role of security, privacy, usability and reputation in the development of online banking. Online Inf. Rev. 2007, 31, 583-603. [CrossRef]

78. Pavlou, P.; Liang, H.; Xue, Y. Understanding and Mitigating Uncertainty in Online Exchange Relationships: A Principal-Agent Perspective. MIS Q. 2007, 31, 105-136. [CrossRef]

79. Eastlick, M.; Lotz, S.; Warrington, P. Understanding online B-to-C relationships: An integrated model of privacy concerns, trust, and commitment. J. Bus. Res. 2006, 59, 877-886. [CrossRef] 
80. Al-Dweeri, R.; Obeidat, Z.; Al-dwwiry, M.; Alshuridh, M.; Alhorani, A. The impact of e-service quality and e-loyalty on online shopping: Moderating effect of e-satisfaction and e-trust. Int. J. Mark. Stud. 2017, 9, 92-103. [CrossRef]

81. Rahhal, W. The effects of service quality dimensions on customer satisfaction: An empirical investigation in syrian mobile telecommunication services. Int. J. Bus. Manag. Invent. 2015, 4, 81-89.

82. Firdous, S.; Farooqi, R. Impact of internet banking service quality on customer satisfaction. J. Internet Bank. Commer. 2017, 22, 1-17.

83. Faisal, C.; Gonzalez-Rodriguez, M.; Fernandez-Lanvin, D.; de Andres-Suarez, J. Web Design Attributes in Building User Trust, Satisfaction, and Loyalty for a High Uncertainty Avoidance Culture. IEEE Trans. Hum.-Mach. Syst. 2017, 47, 847-859. [CrossRef]

84. Zviran, M.; Glezer, C.; Avni, I. User satisfaction from commercial web sites: The effect of design and use. Inf. Manag. 2006, 43, 157-178. [CrossRef]

85. Evanschitzky, H.; Iyer, G.; Hesse, J.; Ahlert, D. E-satisfaction: A re-examination. J. Retail. 2004, 80, $239-247$. [CrossRef]

86. Li, F.; Li, Y. Usability evaluation of e-commerce on B2C websites in China. Procedia Eng. 2011, 15, 5299-5304. [CrossRef]

87. Cai, S.; Xu, Y. Effects of outcome, process and shopping enjoyment on online consumer behavior. Electron. Commer. Res. Appl. 2006, 5, 272-281. [CrossRef]

88. Ya-Wen, Y.; Lin, Y.; Chen, Y.; Chen, J. The exploration of B2B e-auction adaptation strategy in Taiwan. In Proceedings of the Picmet 2010 Technology Management for Global Economic Growth, Phuket, Thailand, 18-22 July 2010.

89. MacKenzie, S.; Podsakoff, P. Common Method Bias in Marketing: Causes, Mechanisms, and Procedural Remedies. J. Retail. 2012, 88, 542-555. [CrossRef]

90. Malhotra, N.; Kim, S.; Patil, A. Common method variance in IS research: A comparison of alternativeapproaches and a reanalysis of past research. Manag. Sci. 2006, 52, 1865-1883. [CrossRef]

91. Hair, J.; Hult, T.; Ringle, C.; Sarsted, M. Advanced Issues in Partial Least Squares Structural Equation Modeling, 2nd ed.; Sage publications: London, UK, 2016.

92. Henseler, J.; Ringle, C.; Sinkovics, R. The Use of Partial Least Squares Path Modeling in International Marketing. In New Challenges to International Marketing (Advances in International Marketing 20); Sinkovics, R., Ghauri, P., Eds.; Emerald Group Publishing Limited: Bingley, UK, 2009; pp. 277-319.

93. Pallant, J. SPSS Survival Manual; McGraw-Hill: London, UK, 2013.

94. Wang, J.; Zou, P.; Li, P. Critical factors and paths influencing construction workers' safety risk tolerances. Accid. Anal. Prev. 2016, 93, 267-279. [CrossRef]

95. Seo, H.; Lee, Y.; Kim, J.; Jee, N. Analyzing Safety Behaviors of Temporary Construction Workers Using Structural Equation Modeling. Saf. Sci. 2015, 77, 160-168. [CrossRef]

96. Fornell, C.; Larcker, D. Evaluating Structural Equation Models with Unobservable Variables and Measurement Error: Algebra and Statistics. J. Mark. Res. 1981, 18, 39-50. [CrossRef]

97. Kline, R. Principles and Practice of Structural Equation Modeling, 4th ed.; Guilford: New York, NY, USA, 2016.

98. Thornton, S.; Henneberg, S.; Naudé, P. Conceptualizing and validating organizational networking as a second-order formative construct. Ind. Mark. Manag. 2014, 43, 951-966. [CrossRef]

99. Hair, J.; Ringle, C.; Sarstedt, M. Partial Least Squares Structural Equation Modeling: Rigorous Applications, Better Results and Higher Acceptance. Long Range Plan. 2013, 46, 1-12. [CrossRef]

100. Paul, R. Multicollinearity: Causes, Effects and Remedies. Available online: http://www.scribd.com/doc/ 52198487/Multicollinearity-Causes-Effects-Remedies (accessed on 18 May 2019).

101. Hair, J.; Sarstdet, M.; Ringle, C.; Gudergan, S. Advanced Issues in Partial Least Squares Structural Equation Modeling, 1st ed.; Sage publications: London, UK, 2017.

102. Henseler, J.; Hubona, G.; Ray, P. Using PLS path modeling in new technology research: Updated guidelines. Ind. Manag. Data Syst. 2016, 116, 2-20. [CrossRef]

103. Vijay, T.; Prashar, S.; Sahay, V. The Influence of Online Shopping Values and Web Atmospheric Cues on E-Loyalty: Mediating Role of E-Satisfaction. J. Theor. Appl. Electron. Commer. Res. 2019, 14, 1-15.

104. Safa, N.; Ismail, M. A customer loyalty formation model in electronic commerce. Econ. Model. 2013, 35, 559-564. [CrossRef] 
105. Choi, Y.; Mai, D. The Sustainable Role of the E-Trust in the B2C E-Commerce of Vietnam. Sustainability 2018, 10, 291. [CrossRef]

106. Safa, N.; von Solms, R. Customers repurchase intention formation in e-commerce. S. Afr. J. Inf. Manag. 2016, 18, 1-9. [CrossRef]

107. Sharma, G. Service Quality, Satisfaction and Loyalty on Online Marketing: An Empirical Investigation. Glob. J. Manag. Bus. Res. 2007, 17, 57-66.

108. Sadeghi, A.; Ghujali, T.; Bastam, H. The Effect of Organizational Reputation on E-loyalty: The Roles of E-trust and E-satisfaction. ASEAN Mark. J. 2018, 10, 1-16.

109. Kim, S.; Noh, M. Determinants Influencing Consumers' Trust and Trust Performance of Social Commerce and Moderating Effect of Experience. Inf. Technol. J. 2012, 11, 1369-1380. [CrossRef]

110. Dharmesti, M.; Nugroho, S. The antecedents of online customer satisfaction and customer loyalty. The Bus. Manag. Rev. 2012, 3, 37-46.

111. Al-Debei, M.; Akroush, M.; Ashouri, M. Consumer attitudes towards online shopping. Internet Res. 2015, 25, 707-733. [CrossRef]

112. Prasad, S.; Gupta, I.; Totala, N. Social media usage, electronic word of mouth and purchase-decision involvement. Asia-Pac. J. Bus. Adm. 2017, 9, 134-145. [CrossRef]

113. Serra-Cantallops, A.; Ramon-Cardona, J.; Salvi, F. The impact of positive emotional experiences on eWOM generation and loyalty. Span. J. Mark.-ESIC 2018, 22, 142-162. [CrossRef]

114. Adwan, A.A. Case study and grounded theory: A happy marriage? An exemplary application from healthcare informatics adoption research. Int. J. Electron. Healthc. 2017, 9, 294-318. [CrossRef]

(C) 2019 by the authors. Licensee MDPI, Basel, Switzerland. This article is an open access article distributed under the terms and conditions of the Creative Commons Attribution (CC BY) license (http://creativecommons.org/licenses/by/4.0/). 